Article

\title{
Summertime Aerosol Radiative Effects and Their Dependence on Temperature over the Southeastern USA
}

\author{
Tero Mielonen ${ }^{1, *(\mathbb{D})}$, Anca Hienola ${ }^{2}(\mathbb{D})$, Thomas Kühn ${ }^{1,3}$, Joonas Merikanto ${ }^{2}$, Antti Lipponen ${ }^{1}(\mathbb{D}$, \\ Tommi Bergman 1,4 (D), Hannele Korhonen ${ }^{2}$ (D) , Pekka Kolmonen ${ }^{2}$, Larisa Sogacheva ${ }^{2}$, \\ Darren Ghent ${ }^{5}$ (D), Mikko R. A. Pitkänen ${ }^{1,3}$, Antti Arola ${ }^{1}$, Gerrit de Leeuw ${ }^{2,6}$ (i) \\ and Harri Kokkola ${ }^{1}$ (i) \\ 1 Finnish Meteorological Institute, 70211 Kuopio, Finland; antti.lipponen@fmi.fi (A.L.); \\ mikko.pitkanen@fmi.fi (M.R.A.P.); antti.arola@fmi.fi (A.A.); harri.kokkola@fmi.fi (H.K.) \\ 2 Finnish Meteorological Institute, 00560 Helsinki, Finland; anca.hienola@fmi.fi (A.H.); \\ joonas.merikanto@fmi.fi (J.M.); hannele.korhonen@fmi.fi (H.K.); pekka.kolmonen@fmi.fi (P.K.); \\ larisa.sogacheva@fmi.fi (L.S.); gerrit.leeuw@fmi.fi (G.d.L.) \\ 3 Department of Applied Physics, University of Eastern Finland, 70211 Kuopio, Finland; \\ thomas.h.kuhn@uef.fi; \\ 4 Royal Netherlands Meteorological Institute, 3731 GA De Bilt, The Netherlands; tommi.bergman@knmi.nl \\ 5 Department of Physics \& Astronomy, University of Leicester, Leicester LE1 7RH, UK; djg20@leicester.ac.uk \\ 6 Department of Physics, University of Helsinki, 00560 Helsinki, Finland \\ * Correspondence: tero.mielonen@fmi.fi; Tel.: +358-50-401-8738
}

Received: 12 April 2018; Accepted: 8 May 2018; Published: 9 May 2018

Abstract: Satellite data suggest that summertime aerosol optical depth (AOD) over the southeastern USA depends on the air/land surface temperature, but the magnitude of the radiative effects caused by this dependence remains unclear. To quantify these radiative effects, we utilized several remote sensing datasets and ECMWF reanalysis data for the years 2005-2011. In addition, the global aerosol-climate model ECHAM-HAMMOZ was used to identify the possible processes affecting aerosol loads and their dependence on temperature over the studied region. The satellite-based observations suggest that changes in the total summertime AOD in the southeastern USA are mainly governed by changes in anthropogenic emissions. In addition, summertime AOD exhibits a dependence on southerly wind speed and land surface temperature (LST). Transport of sea salt and Saharan dust is the likely reason for the wind speed dependence, whereas the temperature-dependent component is linked to temperature-induced changes in the emissions of biogenic volatile organic compounds (BVOCs) over forested regions. The remote sensing datasets indicate that the biogenic contribution increases AOD with increasing temperature by approximately $(7 \pm 6) \times 10^{-3} \mathrm{~K}^{-1}$ over the southeastern USA. In the model simulations, the increase in summertime AOD due to temperature-enhanced BVOC emissions is of a similar magnitude, i.e., $(4 \pm 1) \times 10^{-3} \mathrm{~K}^{-1}$. The largest source of BVOC emissions in this region is broadleaf trees, thus if the observed temperature dependence of AOD is caused by biogenic emissions the dependence should be the largest in the vicinity of forests. Consequently, the analysis of the remote sensing data shows that over mixed forests the biogenic contribution increases AOD by approximately $(27 \pm 13) \times 10^{-3} \mathrm{~K}^{-1}$, which is over four times higher than the value for over the whole domain, while over other land cover types in the study region (woody savannas and cropland/natural mosaic) there is no clear temperature dependence. The corresponding clear-sky direct radiative effect (DRE) of the observation-based biogenic AOD is $-0.33 \pm 0.29 \mathrm{~W} / \mathrm{m}^{2} / \mathrm{K}$ for the whole domain and $-1.3 \pm 0.7 \mathrm{~W} / \mathrm{m}^{2} / \mathrm{K}$ over mixed forests only. The model estimate of the regional clear-sky DRE for biogenic aerosols is similar to the observational estimate for the whole domain: $-0.29 \pm 0.09 \mathrm{~W} / \mathrm{m}^{2} / \mathrm{K}$. Furthermore, the model simulations showed that biogenic emissions have a significant effective radiative forcing (ERF) in this region: $-1.0 \pm 0.5 \mathrm{~W} / \mathrm{m}^{2} / \mathrm{K}$. 
Keywords: aerosols; direct radiative effect; effective radiative forcing; remote sensing; atmospheric modeling; biogenic volatile organic compounds; secondary organic aerosols

\section{Introduction}

Aerosol particles are an important regulator of the Earth's climate. They scatter and absorb incoming solar radiation (e.g., [1]) and can act as initial formation sites for cloud droplets and thereby modify the properties and lifetime of clouds [2-4]. The magnitude of aerosol radiative effects remains the single largest uncertainty in the current estimates of the anthropogenic radiative forcing [5]. One of the key quantities needed for accurate estimates of anthropogenic radiative forcing is quantitative knowledge of the radiative effects of natural aerosol-after all, it is the change from the natural background that is important when quantifying human influence on climate. Recent studies have highlighted that the uncertainties in natural aerosol emissions may bias our current estimates of aerosol forcing more than the uncertainties associated with anthropogenic emissions [6]. Furthermore, our current understanding of future changes in natural aerosol radiative effects is very poor.

The dominant source of natural aerosols over the Earth's vast forested regions is biogenic volatile organic compounds [7], which are oxidized in the atmosphere, forming semi-, low-, or non-volatile organic compounds [8]. Consequently, these compounds can condense onto existing aerosol particles or participate in new particle formation to form secondary organic aerosols (SOA) and significantly modify the chemical and optical properties of the particles [9]. In accordance with the expected positive temperature dependence of BVOC emissions [10-13], several previous studies have shown that some aerosol properties, such as mass concentration and the number of cloud active aerosol particles, i.e., cloud condensation nuclei $(\mathrm{CCN})$, indeed correlate positively with temperature at many forested sites (e.g., [14,15]). Therefore, BVOC emissions could introduce a regionally relevant cooling feedback in a warming climate [9]. However, the evidence for a link between air temperature and the aerosol radiative effects due to increased BVOC emissions is not yet definite because in addition to BVOC emissions photochemistry and synoptic meteorology also depend on temperature and can affect SOA formation (e.g., [16]). Aerosol direct effects can be quantified via aerosol optical depth (AOD) from, e.g., satellites. Slowik et al. [17] observed a positive correlation between in situ observed SOA and regional satellite-based AOD in Ontario, Canada during periods of elevated temperature. Similarly, Goldstein et al. [18] detected an exponential dependence of the AOD on the temperature in the southeastern USA, and hypothesized that it arose from enhanced natural BVOC emissions on warmer days. The links between temperature, BVOC emissions, and AOD are further complicated over regions with extensive $\mathrm{SO}_{2}$ emissions, such as in the southeastern USA, due to the effect of isoprene oxidation on sulphate aerosol formation: the major oxidation products of isoprene are peroxides, which are generally attributed to the increased summertime formation of sulphate via aqueous phase reactions [18]. Therefore, changes in $\mathrm{SO}_{2}$ emissions also affect the relationship between BVOC emissions and AOD.

The southeastern USA is an interesting location for aerosol studies due to the strong interplay between biogenic and anthropogenic aerosol sources in that region. Consequently, extensive studies on aerosol over that region have been carried out (e.g., [19-27]). These studies concentrated on aerosol chemistry, trends in aerosols and the formation of SOA. For example, $\mathrm{Xu}$ et al. [23] showed that anthropogenic pollution enhances isoprene-derived SOA concentrations significantly and a major fraction of organic aerosol is mediated by the pollution in the southeastern USA during summer. However, only three studies have estimated the direct radiative effect of aerosols in this region: Carrico et al. [28] estimated the direct aerosol radiative effect in the metropolitan Atlanta to be $-11 \pm 6 \mathrm{~W} / \mathrm{m}^{2}$ in the summer of 1999 , Goldstein et al. [18] estimated the aerosol radiative effect due to seasonal changes in aerosol load to be $-3.9 \mathrm{~W} / \mathrm{m}^{2}$, and Attwood et al. [24] estimated that between 
the summers of 2001 and 2013 the diurnally averaged surface radiative effect changed by $8 \mathrm{~W} / \mathrm{m}^{2}$ due to decreasing aerosol mass.

The main objective of this study was to provide a quantitative estimate of the regional aerosol direct radiative effect caused by the temperature-dependent biogenic emissions over the southeastern USA. The research was carried out using remote sensing observations and the findings were evaluated with aerosol-climate model sensitivity simulations. With this combination of observations and model simulations the significance of biogenic emissions on the temperature dependence of AOD and the corresponding radiative effect was quantified. Despite the large amount of research done in this region, to our knowledge this is the first time the temperature-dependent summertime aerosol radiative effects over the southeastern USA have been quantified.

\section{Methodology}

Key remote sensing data used in this study were the aerosol optical depth and land surface temperature products available from the European Space Agency (ESA) Aerosol_cci $[29,30]$ and ESA DUE GlobTemperature (Available online: http://www.globtemperature.info/) projects, together with ancillary data, such as tropospheric column density of nitrogen dioxide $\left(\mathrm{NO}_{2}\right)$ and land cover type (Table 1). These observations were used to analyse the temperature dependence of summertime AOD and the reasons behind the observed behaviour. For the modelling work we used the aerosol-chemistry climate model ECHAM-HAMMOZ [31-35], which describes the relevant atmospheric aerosol processes. We performed several sensitivity simulations in order to identify whether biogenic emissions could be responsible for the observed temperature dependence of the AOD. The regional radiative effects of the temperature-dependent AOD component were estimated from both observations and simulations. The study domain covered the land area over the southeastern USA $\left(70-90^{\circ} \mathrm{W}\right.$ and $30-37.5^{\circ} \mathrm{N}$ ) for the years 2005-2011. This time period was chosen because it was covered by all the satellite instruments used in this study. We also used land cover type data to evaluate differences between the temperature dependence of AOD over the most abundant vegetation types. A more detailed description of each dataset and the model simulations are given below.

Table 1. Satellite products used in the project.

\begin{tabular}{cccc}
\hline Product & Usage & $\begin{array}{c}\text { Instrument } \\
\text { (Data Depository) }\end{array}$ & Product Type \\
\hline $\begin{array}{c}\text { Aerosol optical depth } \\
\text { (AOD) }\end{array}$ & $\begin{array}{c}\text { Proxy for aerosol load, } \\
2005-2011\end{array}$ & $\begin{array}{c}\text { AATSR } \\
\text { (Aerosol_cci/ESA) }\end{array}$ & $\begin{array}{c}\text { Level 3, } \\
1 \times 1 \text { deg, daily }\end{array}$ \\
\hline $\begin{array}{c}\text { Land surface temperature } \\
(\mathrm{LST})\end{array}$ & $\begin{array}{c}\text { Temperature, } \\
\text { 2005-2011 }\end{array}$ & $\begin{array}{c}\text { AATSR } \\
\text { (GlobTemperature/ESA) }\end{array}$ & $\begin{array}{c}\text { Level 3, } \\
0.01 \times 0.01 \mathrm{deg} \text {, daily }\end{array}$ \\
\hline $\begin{array}{c}\text { Nitrogen dioxide } \\
\left(\mathrm{NO}_{2}\right)\end{array}$ & Proxy for anthropogenic emissions, & OMI & Level 3, \\
(ACDISC/NASA) & $0.25 \times 0.25$ deg, daily \\
\hline IGBP Land cover type & Proxy for vegetation type, & MODIS & Level 3, \\
& $2005-2011$ & (LPDAAC/NASA) & $0.05 \times 0.05$ deg, yearly \\
\hline
\end{tabular}

\subsection{Spaceborne Observations}

\subsubsection{AATSR}

The core datasets for this study were provided by the Advanced Along-Track Scanning Radiometer (AATSR), which flew on the ESA polar orbiting Environmental Satellite ENVISAT (2002-2012). It was a dual view imaging spectrometer with seven wavebands, four of them in the visible and near-infrared $(0.555,0.659,0.865$, and $1.6 \mu \mathrm{m})$ and three in the shortwave infrared-thermal infrared $(3.7,11$, and $12 \mu \mathrm{m})$. AATSR had a swath width of $512 \mathrm{~km}$ and the spatial resolution at nadir view was $1 \times 1 \mathrm{~km}^{2}$. The nadir view and the forward view at $55^{\circ}$ incident angle to the surface allowed for near-simultaneous observation of the same area on the Earth's surface through two different 
atmospheric columns within $\sim 2 \mathrm{~min}$. The overpass time for the southeastern USA was approximately 10:00 a.m. local solar time.

From the AATSR, clear-sky AOD data available from the ESA Aerosol_cci project and LST data from ESA's DUE GlobTemperature project were used. More specifically, daily Level 3 AOD data (version 1.42) with a spatial resolution of $1^{\circ} \times 1^{\circ}$ were chosen because of the similarity in their spatial resolution to the resolution of the climate model, which enabled a comparison between the observations and simulations on a similar spatial scale. The Level 3 LST data with higher resolution $\left(0.01^{\circ} \times 0.01^{\circ}\right)$ were re-gridded to $1^{\circ} \times 1^{\circ}$ resolution to match the resolution of the AOD data.

Several algorithms have been developed for the retrieval of AOD from the AATSR observations. In this work we used the AOD retrieved with the AATSR Dual-View (ADV) algorithm, which was developed at the Finnish Meteorological Institute [36]. Over land, the algorithm uses both nadir and forward view measurements of top-of-the-atmosphere (TOA) reflectance to decouple atmospheric and surface contributions from the observed signal. The main product of the retrieval is AOD, including pixel-level uncertainties. Validation results have shown that the ADV AOD values agree well with sun photometer measurements $(r=0.85$, RMSE $=0.09$ over land). The Level 3 AOD product is an average of the Level 2 AOD product $\left(10 \times 10 \mathrm{~km}^{2}\right)$, which is retrieved from cloud-cleared observations. After the retrieval, the Level 2 AOD values are post-processed to remove the remaining cloud contamination [37]. For a more detailed description of the algorithm see [36] and the algorithm's Algorithm Theoretical Basis Document [38]. In addition to the average AOD values, the Level 3 data product includes pixel specific standard deviations and they were used as uncertainty estimates in the analysis. We assumed that the uncertainties are strongly correlated temporally; thus, the seasonal uncertainty estimates were calculated as simple averages. To ensure that this relatively new AOD product was suitable for our analysis over the studied region, it was compared with AOD retrievals available from Multi-angle Imaging SpectroRadiometer (MISR) observations and with previously published AOD trends for this region. The AOD products were in good agreement and the AATSR product exhibited trends similar to those published in the literature (see Figures S1 and S2, and Table S1 for more information).

The LST algorithm uses pixel-by-pixel TOA radiometrically and geometrically calibrated brightness temperatures from the 11 and $12 \mu \mathrm{m}$ channels. The retrieval coefficients are dependent on the biome, fractional vegetation cover, precipitable water, satellite zenith view angle, and the time of day (day or night). Both the fractional vegetation cover and precipitable water are seasonally dependent, whereas the biome is invariant. The Level 3 product exploited here has been cloud-cleared and re-gridded onto a regular equal-angle grid. For more information, see the AATSR LST Algorithm Theoretical Basis Document [39] and the Validation Report [40]. The LST data also include pixel level uncertainties that were incorporated into the analysis. In practice, we averaged the uncertainty values in a similar way as we did for the AOD values. Averaging the uncertainties provides us with a conservative uncertainty estimate, since in error propagation random components are reduced, but we do not consider this; instead we treat them as systematic errors. In the analysis, we modelled the data uncertainty as normally distributed with zero mean and standard deviation of half the given uncertainty. With this uncertainty model, the true data points were assumed to lie within the given uncertainty range with a probability of $95 \%$.

\subsubsection{OMI}

The Dutch-Finnish-built Ozone Monitoring Instrument (OMI) is a nadir-viewing pushbroom UV/Visible instrument. It is onboard NASA's EOS-Aura satellite and part of the A-Train satellite constellation. OMI measures backscattered radiances in three wavelength intervals: $270-310 \mathrm{~nm}$ (UV-1), 310-365 nm (UV-2), and 350-500 nm (visible) at spectral resolutions of 0.42-0.63 nm [41]. It has a swath width of $2600 \mathrm{~km}$ and spatial resolution of $13 \times 48 \mathrm{~km}^{2}$ at nadir for the UV-1 channel, and $13 \times 24 \mathrm{~km}^{2}$ for the UV-2 and visible channels. OMI measures ozone, trace gases (e.g., $\mathrm{NO}_{2}, \mathrm{SO}_{2}, \mathrm{HCHO}, \mathrm{BrO}, \mathrm{CHOCHO}$, $\mathrm{OClO})$, aerosols and clouds. 
In this work, the Level 3 tropospheric $\mathrm{NO}_{2}$ retrievals from the OMNO2d product were used [42]. It consists of only good-quality pixel-level data that are averaged into a $0.25^{\circ} \times 0.25^{\circ}$ global grid, and thus we re-gridded the data into $1^{\circ} \times 1^{\circ}$ resolution to match the AATSR observations. The data contain $\mathrm{NO}_{2}$ column densities for all atmospheric conditions where the cloud fraction is less than $30 \%$. For cloud fractions larger than $30 \%$ it becomes impossible to distinguish pollution from natural variation because high clouds mask the tropospheric contribution. For more information, see the documents provided by NASA GES DISC $[43,44]$. The $\mathrm{NO}_{2}$ data do not include information on the uncertainty of the retrieved values. Therefore, we used an uncertainty estimate of $\pm 20 \%$, as suggested by Lamsal et al. [45], who evaluated the $\mathrm{NO}_{2}$ product over the eastern USA. The standard deviation of the data was estimated in a similar manner as for the AATSR LST data. In this research, the tropospheric $\mathrm{NO}_{2}$ data were used as a proxy for anthropogenic emissions. $\mathrm{NO}_{2}$ can be considered a proxy for anthropogenic influence since the main sources of nitrogen oxides in the studied region are combustion in transportation and electricity generating units, with some emissions also originating from industrial, commercial and residential sources [25]. Fertilized croplands could also be important $\mathrm{NO}_{2}$ sources [46], and in our analysis they can be considered as anthropogenic emissions. Although $\mathrm{NO}_{2}$ is not emitted from all anthropogenic sources, it exhibits a similar decreasing trend to $\mathrm{SO}_{2}$ in this region [47]. Thus it is a suitable proxy for estimating the level of anthropogenic contribution to seasonally averaged AOD. To confirm that the tropospheric $\mathrm{NO}_{2}$ retrievals from OMI represent anthropogenic pollution levels, we compared them with in situ observations of sulphate particle mass performed at the Interagency Monitoring of PROtected Visual Environments (IMPROVE) sites in the southeastern USA [48]. The comparison was done using summertime averages of tropospheric $\mathrm{NO}_{2}$ column densities covering the entire study region and seasonal averages of sulphate particle mass combined from 12 IMPROVE sites within the region. This comparison showed a strong positive correlation between the observations ( $r=0.98)$, which further supports the assumption that the tropospheric $\mathrm{NO}_{2}$ observations can be used as a proxy for anthropogenic influence (see Figure $\mathrm{S} 3$ for more information). Lightning also produces $\mathrm{NO}_{2}$, thus to evaluate the effect of lightning to the level of tropospheric $\mathrm{NO}_{2}$ we used observations of lightning flash rates [49]. Based on the flash rates, summers 2010 and 2011 had the highest lightning activity during the studied period. As these summers had low tropospheric $\mathrm{NO}_{2}$ concentrations, it indicates that anthropogenic sources have a larger effect on the seasonal level of tropospheric $\mathrm{NO}_{2}$ than lightning.

\subsubsection{MODIS}

The Moderate-Resolution Imaging Spectroradiometers (MODIS, [50]) are passive satellite instruments aboard two satellites: Terra and Aqua. Having a swath width of $2300 \mathrm{~km}$, these instruments cover the Earth's surface every 1 to 2 days. The instruments have 36 spectral bands ranging in wavelength from $0.4 \mu \mathrm{m}$ to $14.4 \mu \mathrm{m}$. Two of the bands are imaged at a nominal resolution of $250 \mathrm{~m}$ at nadir, five bands at $500 \mathrm{~m}$ and the remaining 29 bands at $1 \mathrm{~km}$. The Terra satellite was launched in 1999 and Aqua in 2002.

In order to analyse how the biogenic emissions depend on the underlying vegetation types we used the Land Cover Type Climate Modelling Grid (CMG) product (MCD12C1, [51]). The product provides the dominant land cover types on a $0.05^{\circ} \times 0.05^{\circ}$ global grid. It contains three classification schemes that describe the land cover properties derived from observations spanning a year's input of MODIS observations. The primary land cover scheme, which identifies 17 land cover classes defined by the International Geosphere Biosphere Programme (IGBP), was used in this work. We re-gridded the data into $1^{\circ} \times 1^{\circ}$ resolution to match the other observations by calculating the fraction of each land cover class within the $1^{\circ} \times 1^{\circ}$ pixels. We considered a pixel to be dominated by a certain land cover class if the fraction of that type was $50 \%$ or larger. In the analysis, we only used pixels dominated by the three most abundant land cover classes in the southeastern USA in 2011: woody savannas, mixed forests and cropland/natural mosaic. The studied domain included in total $821^{\circ} \times 1^{\circ}$ pixels. Of those pixels, 22 were classified as woody savannas, 13 as mixed forests and 10 as cropland/natural mosaic. 
The other land cover classes dominated fewer than five $1^{\circ} \times 1^{\circ}$ pixels, thus they did not provide enough observations for a statistically robust analysis. We also checked how the land cover types had changed during the studied period but no large-scale changes were found.

\subsection{Aerosol-Climate Model}

In this study, the contribution of biogenic sources to the temperature dependence of the AOD over the southeastern USA was also assessed using the development version of the global aerosol-climate model ECHAM-HAMMOZ [31-35], version ECHAM6.1-HAM2.2-SALSA. The atmospheric circulation model ECHAM solves the fundamental equations for the atmospheric flow, physics and tracer transport. The aerosol model HAM takes advantage of the Sectional Aerosol module for Large-Scale Applications (SALSA), which was used to calculate the aerosol microphysics [33,35,52]. SALSA describes the aerosol population consisting of sulphate $\left(\mathrm{SO}_{4}\right)$, sea salt, organic carbon $(\mathrm{OC})$, black carbon (BC), mineral dust, and water, and uses seven size sections with moving centres to cover the size range from $3 \mathrm{~nm}$ to $10 \mu \mathrm{m}$. External mixing of the aerosol particles was tracked with seven additional sections. Anthropogenic aerosol emissions were described with AeroCom-II Atmospheric Chemistry and Climate Model Intercomparison Project (ACCMIP) data $[53,54]$. For biomass burning emissions, the Global Fire Emissions Database (GFEDv2; [55]) was used. Annual and monthly averages were used for the anthropogenic and biomass burning emissions, respectively. The activation of aerosol particles into cloud droplets was calculated with the semi-empirical parameterization of Lin and Leaitch (1997) [56].

In our implementation of SOA formation in ECHAM-HAMMOZ, organic mass is emitted both as primary organic matter (POM) and in the form of volatile organic compounds (VOC). Here we consider xylene (XYL), toluene (TOL), and benzene (BENZ) as anthropogenic VOCs, which are entered into the model based on the AeroCom II ACCMIP emission inventories [53,54]. BVOC emissions are computed online using the Model of Emissions of Gases and Aerosols from Nature (MEGAN, [57]). In our implementation, isoprene (ISOP) and monoterpenes (MTP) are considered for BVOC emissions. POM is emitted only from anthropogenic sources and wildfires.

Once emitted, all VOCs are subject to gas-phase oxidation. Here we consider the hydroxyl radical $(\mathrm{OH})$ and ozone $\left(\mathrm{O}_{3}\right)$ as daytime oxidants and nitrate radical $\left(\mathrm{NO}_{3}\right)$ as a night time oxidant. The concentrations of $\mathrm{OH}, \mathrm{O}_{3}$ and $\mathrm{NO}_{3}$ are prescribed with pre-computed climatological 3D fields from the MOZART model [58]. The applied reaction coefficients are listed in Table 2 and the reaction equation is given in the table caption. The oxidation products are grouped into two categories, the first of which contains semi- and non-volatile compounds that partition onto aerosols directly from the gas phase. The second category contains organic compounds that form SOA through aqueous phase chemistry.

Table 2. Reaction coefficients for VOC oxidation in the form $k=k_{0} \exp \left(E_{a}^{\prime} / T\right)$, with $k_{0}$ in $\mathrm{m}^{3} \mathrm{~mol}^{-1} \mathrm{~s}^{-1}$ and $E_{a}^{\prime} \equiv E_{a} / R$ in $\mathrm{K}, \mathrm{k}=\mathrm{k}_{0} \exp \left(\mathrm{E}_{\mathrm{a}}^{\prime} / \mathrm{T}\right)$. where $R$ is the gas constant, $E_{a}$ is the activation enthalpy, $T$ is temperature, and $k_{0}$ the reference reaction coefficient at $298 \mathrm{~K}$.

\begin{tabular}{ccccccc}
\hline & \multicolumn{2}{c}{$\mathrm{OH}$} & \multicolumn{2}{c}{$\mathrm{O}_{3}$} & \multicolumn{2}{c}{$\mathrm{NO}_{3}$} \\
\cline { 2 - 7 } & $k_{\mathbf{0}}$ & $\boldsymbol{E}_{\boldsymbol{a}}^{\prime}$ & $\boldsymbol{k}_{\mathbf{0}}$ & $\boldsymbol{E}_{\boldsymbol{a}}^{\prime}$ & $\boldsymbol{k}_{\mathbf{0}}$ & $\boldsymbol{E}_{\boldsymbol{a}}^{\prime}$ \\
\hline XYL & $2.31 \times 10^{-11}$ & 0 & 0.0 & 0 & $2.6 \times 10^{-16}$ & 0 \\
TOL & $1.81 \times 10^{-12}$ & 338 & 0.0 & 0 & 0.0 & 0 \\
BENZ & $2.33 \times 10^{-12}$ & -193 & 0.0 & 0 & 0.0 & 0 \\
ISOP & $2.7 \times 10^{-11}$ & 390 & $1.03 \times 10^{-14}$ & -1995 & $3.15 \times 10^{-12}$ & -450 \\
MTP & $1.2 \times 10^{-11}$ & 440 & $6.3 \times 10^{-16}$ & -580 & $1.2 \times 10^{-12}$ & 490 \\
GLYX & 0.0 & 0 & 0.0 & 0 & $6.0 \times 10^{-13}$ & -1900 \\
IEPOX & $3.56 \times 10^{-11}$ & 0 & 0.0 & 0 & 0.0 & 0 \\
\hline
\end{tabular}

The compounds in the first category are grouped according to their volatility using the volatility basis set (VBS) approach $[59,60]$. In our implementation we group them into three volatility 
classes based on their saturation vapour pressure, $C^{*}$ : VBS0 $\left(C^{*}=0 \mu \mathrm{g} \mathrm{cm}^{-3}\right.$; non-volatiles), VBS1 ( $\mathrm{C}^{*}=1 \mu \mathrm{g} \mathrm{cm}^{-3}$; low-volatiles), and VBS10 ( $\mathrm{C}^{*}=10 \mu \mathrm{g} \mathrm{cm}^{-3}$; semi-volatiles). The second category, which represents species forming SOA in the aqueous phase, contains isoprene epoxydiols (IEPOX) and glyoxals (GLYX). Gas phase IEPOX and GLYX are removed via further oxidation, and the applied reaction coefficients are also listed in Table 2.

The partitioning of SOA forming compounds is assumed to be a non-equilibrium process and it is calculated by solving the condensation equations for all size classes using the Analytical Predictor of Condensation method [61,62]. Aqueous production of SOA by IEPOX and GLYX is modelled via their reactive partitioning into aerosol water [63], with partitioning coefficients obtained from Kampf et al. [63] for GLYX and Nguyen et al. [64] for IEPOX. Partitioning of organic compounds into cloud water was not considered in this study.

The simulations were done using T63 horizontal resolution (roughly $1.9^{\circ} \times 1.9^{\circ}$ ) and 31 pressure levels that reached up to $10 \mathrm{hPa}$. The model's large scale circulation (divergence, vorticity and surface pressure) in our simulations was nudged towards the ECMWF reanalysis data (ERA-Interim; [65]) to ensure compatibility between the model and the observed atmospheric conditions. The simulation period was 2002-2010, with a three-month spin-up. It has to be noted that, due to its coarse resolution, the climate model is not expected to fully replicate the observations, but as it includes a state-of-the-art description of biogenic SOA it is a suitable tool to investigate the magnitude of the effect of biogenic aerosol sources on the aerosol load over the southeastern USA. The intention of the model analysis was not to reproduce all the details of the observations. Instead, it was used as a tool to estimate the biogenic contribution to AOD using sensitivity simulations. This enabled us to evaluate whether the observed relationship between temperature and AOD could be explained by biogenic aerosols.

In order to do this, two model simulations were undertaken: a control simulation where all the schemes described above were in use (CONTROL) and a sensitivity simulation that did not include biogenic SOA precursors (noBIOSOA).The significance of biogenic emissions was then estimated by comparing the sensitivity simulation to the CONTROL run.

To ensure that the ECHAM-HAMMOZ model could reproduce the main AOD and LST characteristics over the studied region, the modelling results were compared with AATSR observations. The monthly AOD and LST averages from the CONTROL simulation were in a reasonable agreement with the values from the AATSR retrievals for the years 2003-2010. The correlation coefficients for the AOD and LST values were 0.77 and 0.94, respectively. The simulated AOD values overestimated the lowest AOD values but underestimated the largest ones. (See Figures S4 and S5 for more details).

\subsection{Meteorological Data}

Since we study the temperature-driven changes in AOD, we will also have to consider processes that simultaneously affect both temperature and aerosol causing common cause variation. Changes in temperature can be connected to changes in other meteorological quantities, such as precipitation and wind. In addition, the changes in these quantities may affect aerosol loads. In order to investigate the possible effects of meteorology on the aerosol population, we used precipitation and wind data from the ERA-Interim archive [65]. For the comparisons with the satellite observations, we used the daily forecasts for local noon with $1^{\circ} \times 1^{\circ}$ degree spatial resolution. We collocated the daily meteorological values of total precipitation, boundary layer height, and the U10 (east-west direction) and V10 (north-south direction) wind speed components at $10 \mathrm{~m}$ altitude with the satellite observations for each pixel in the study domain for the years 2005-2011. For the linear fitting, we assumed a 20\% uncertainty for the meteorological parameters.

\subsection{Regression Analysis}

In order to estimate the magnitude of the linear relationships between the different observed and simulated variables analysed in this study, we fitted linear models to the datasets using Orthogonal Distance Regression (ODR) [66]. By carrying out the linear model parameter estimation using this 
method the uncertainties in both the dependent and independent variables were taken into account thus producing more realistic estimates for the linear model parameters than by using the ordinary least squares fitting [67]. In practice, the observations with smaller uncertainties constrain the linear model more than the observations with larger uncertainties. Furthermore, the used approach enabled computation of confidence intervals for the estimated parameters. The ODR analysis was carried out using the Python package scipy.odr, which utilizes the FORTRAN-77 library ODRPACK [68].

As discussed in previous sections, the satellite products have uncertainty/variability estimates that can be used in the fitting of the linear models. The climate model data, on the other hand, do not include such information. Therefore, we used the variability between the daily values within the summer months to estimate the representability of the seasonal averages for each simulated pixel using the bootstrapping method [69]. Bootstrapping is a commonly used statistical method that may be used to assign measures of uncertainty to sample estimates. In practice, we constructed 1000 data point sets by randomly sampling from the daily averages and calculated averages for these new sets. Furthermore, the standard deviations of the set averages were computed and used as the measure of variability in the analysis.

\section{Results and Discussion}

\subsection{Temperature Dependence of Summertime AOD over the Southeastern USA}

As the first step, we investigated the relationship between AOD and LST using the AATSR observations. The anomalies of the regional mean LST and AOD were calculated for the summers (JJA) of the years 2005-2011 by subtracting the average of all the summers from the yearly summer averages. Summer averages were calculated from monthly averages to ensure that each month had an equal weight in the seasonal average.

Figure 1 presents a scatterplot of the observed AOD versus LST anomalies for the summers 2005-2011 and apparently, there is no clear correlation between these anomalies for these years. This lack of correlation seems to be in contradiction with the results of Goldstein et al. [18], who presented a linear correlation between AOD (retrieved from MISR data) and temperature anomalies (from Goddard Institute for Space Studies (GISS)) for the years 2000-2005 averaged over the same region.

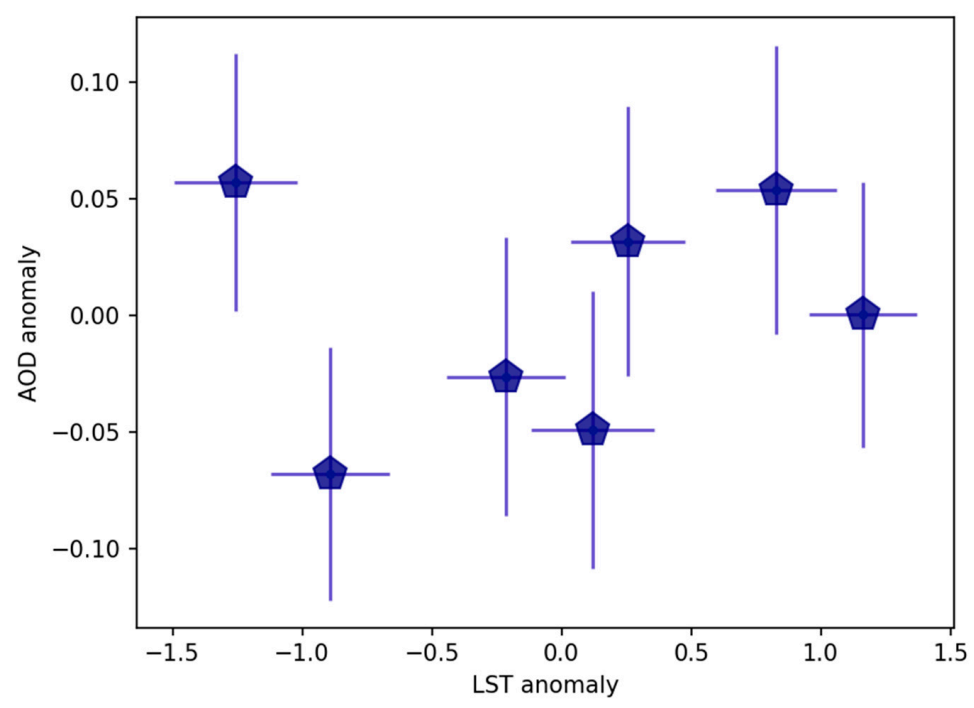

Figure 1. Summertime anomalies (JJA) of aerosol optical depth (AOD) vs. regional mean land surface temperature (LST) over the southeastern USA for the years 2005-2011. Pentagons represent averages over the whole domain. LST and AOD are from the L3 AATSR. The error bars represent the uncertainty of the observations (one standard deviation). 
To further investigate this apparent discrepancy, we compared the time series of AOD, LST and other quantities that might influence the AOD in this region (e.g., tropospheric $\mathrm{NO}_{2}$ column densities, total column water vapour [70], soil moisture [71], fire radiative power [72], and meteorological parameters [65]) for the summers of 2005-2011. Examples of these time series are shown in Figure 2. Their comparison shows that LST and AOD have some similar features with high values in 2007 and 2011 and a minimum in 2009, but their correlation coefficient is only 0.16 . The temporal variations of tropospheric $\mathrm{NO}_{2}$ column densities and AOD are in better agreement with similar features and a much higher correlation $(r=0.92)$. Finally, the comparison between AOD and southerly wind speed at $10 \mathrm{~m}$ (SW10) shows no correlation $(r=-0.02)$. The other quantities not shown in Figure 2 did not exhibit any clear relationships with AOD but that does not mean that AOD could not be affected by those quantities during certain summers. To conclude, a significant correlation is observed only between summertime AOD and tropospheric $\mathrm{NO}_{2}$ column densities over the southeastern USA.
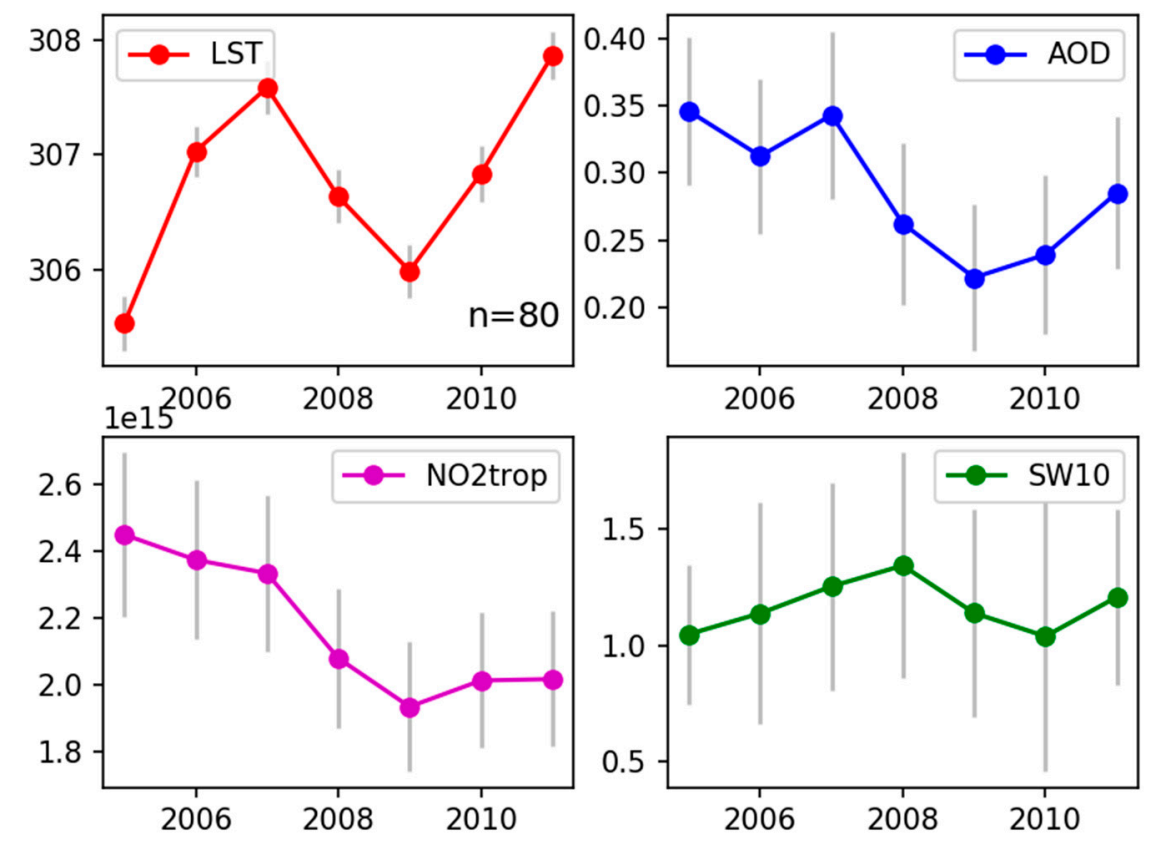

Figure 2. Summer averages of LST (K), AOD, tropospheric $\mathrm{NO}_{2}$ column densities (molecules $/ \mathrm{cm}^{2}$ ) and the southerly wind speed at $10 \mathrm{~m}(\mathrm{~m} / \mathrm{s})$ over the southeastern USA, for the years 2005-2011. AOD and LST are based on the L3 AATSR data while the tropospheric $\mathrm{NO}_{2}$ column densities are based on the L3 OMI and the meridional wind speed on the ERA-Interim data. The error bars represent the uncertainty of the data points and $n$ is the number of data points used in the calculation of each summer average.

As tropospheric $\mathrm{NO}_{2}$ is predominantly generated from anthropogenic sources [73], Figure 2 indicates that the summertime AOD levels in this region are mainly related to the amount of anthropogenic emissions. The $\mathrm{NO}_{2}$ column densities have decreased between 2005 and 2011 (see Table S2 for details) and this decrease is in line with the reductions of anthropogenic emissions in the studied region (e.g., $[24,25,47,74,75])$. The emissions have decreased for several years due to emission control measures, but the economic crisis in 2007-2009 augmented the reduction rate of the emissions further [76], which is also visible in Figure 2.

The AOD can be affected by anthropogenic emissions of both primary aerosol particles and precursor gases and also by enhancing SOA formation from biogenic precursors (e.g., $[16,19,20]$ ). Veefkind et al. [73] showed that over the southeastern USA summertime AOD values and formaldehyde (used as an indicator for non-methane VOCs) column densities are strongly correlated, which implies that SOA formation could have a more important contribution to AOD than primary emissions. Correspondingly, Zhang et al. [77] found that monoterpene SOA accounted for about half of the 
total fine mode organic aerosol. Furthermore, Rattanavaraha et al. [19] and Budisulistiorini et al. [20] showed that in the southeastern USA almost all isoprene-derived SOA is formed through the low- $\mathrm{NO}_{\mathrm{x}}$ pathway and sulphate enhances the SOA yield by providing particle water and acidity. Under low- $\mathrm{NO}_{\mathrm{x}}$ conditions SOA yields from isoprene are expected to be larger because peroxy radicals are not able to react with NO. Instead, they produce IEPOX through a $\mathrm{HO}_{\mathrm{x}}$-mediated mechanism [78-80]. The actual mechanism responsible for the anthropogenic effect on biogenic SOA formation cannot be discerned with the remote sensing datasets at our disposal, but the total effect of the anthropogenic emissions on AOD level can be estimated.

In order to gain a better understanding of the effects of anthropogenic and biogenic emissions on the AOD, we investigated the time series shown in Figure 2 and Table S2 in more detail. As Figure 2 shows, the tropospheric $\mathrm{NO}_{2}$ column densities decreased linearly between the summers 2005 and 2007. At the same time LST increased by $2 \mathrm{~K}$, whereas AOD did not exhibit a clear trend. Moreover, the AOD values in the summers of 2007 and 2011 were larger than in the preceding summers while in these same summers the tropospheric $\mathrm{NO}_{2}$ column densities were smaller than in the preceding summers. Therefore, it is not likely that the high AOD values in these summers are due to increased $\mathrm{NO}_{2}$ concentrations. Instead, this increase in AOD in the summers of 2007 and 2011 with respect to that in the preceding summers could be caused by the increase in biogenic emissions in these years in response to enhanced temperatures. However, the comparison of the periods 2005-2007 and 2009-2011 indicates that the decreasing anthropogenic emissions have a larger effect on the AOD level than the increasing temperature. Both periods undergo similar increase in temperature but the AOD and tropospheric $\mathrm{NO}_{2}$ levels do not exhibit a similar increase over that period. Thus, the data in Figure 2 suggest that there is a temperature-dependent component in the summertime AOD over the southeastern USA as Goldstein et al. [18] reported but its impact on the total AOD (anthropogenic + biogenic AOD) is considerably smaller than the impact of anthropogenic emissions and therefore, it is not clearly visible in our data due to the overwhelming effect of $\mathrm{NO}_{2}$ reductions during the period used in the analysis. Therefore, Figure 1 appeared at first to contradict the findings of Goldstein et al. [18].

To quantify the effects of temperature-induced biogenic emissions and anthropogenic emissions on the AOD a statistical analysis was undertaken using data averaged over individual $1^{\circ} \times 1^{\circ}$ pixels. Even though the correlation coefficients between the domain-averaged parameters can be high, a statistically robust relation cannot be derived due to the small number of data points and the significant uncertainties in the observational values. For a robust estimate of the impact of different emission sources on AOD, we calculated the anomalies of all the parameters for individual $1^{\circ} \times 1^{\circ}$ pixels within the studied domain (82 pixels in total) in a similar manner as we did for the whole region. We calculated pixel-wise anomalies to remove the spatial gradients that might complicate the analysis. When the pixel-wise anomalies of summertime tropospheric $\mathrm{NO}_{2}$ column densities are compared to the corresponding AOD anomalies, a linear dependence can be seen, as the linear fit with $95 \%$ confidence intervals in Figure 3 shows. It is worth noting that the linear relation derived based on the $1^{\circ} \times 1^{\circ}$ pixels compares well with the domain anomalies, which indicates that the relationship based on the individual pixels is also representative for the whole region.

This relationship between $\mathrm{AOD}$ and $\mathrm{NO}_{2}$ explains most of the variation in AOD but not all of it. To investigate whether a dependence of the AOD on LST or other parameters could be quantified despite the large changes in anthropogenic emissions we used Orthogonal Distance Regression (ODR) to separate the different factors affecting the total AOD level. We checked all available quantities (e.g., tropospheric $\mathrm{NO}_{2}$ column densities, total column water vapour, soil moisture, fire radiative power, and meteorological parameters) to see whether AOD exhibits a statistically reliable relationship with any of them. The reliability of the linear relationships was based on the $95 \%$ confidence intervals of the linear fits. For example, fire radiative power, which we used as a proxy for biomass burning emissions, did not exhibit any kind of relationship with AOD, which is a clear indication that biomass burning emissions do not explain the variation in AOD level. This was to be expected as the contribution of biomass burning emissions to the aerosol load in this region is at a minimum during summers [81]. 


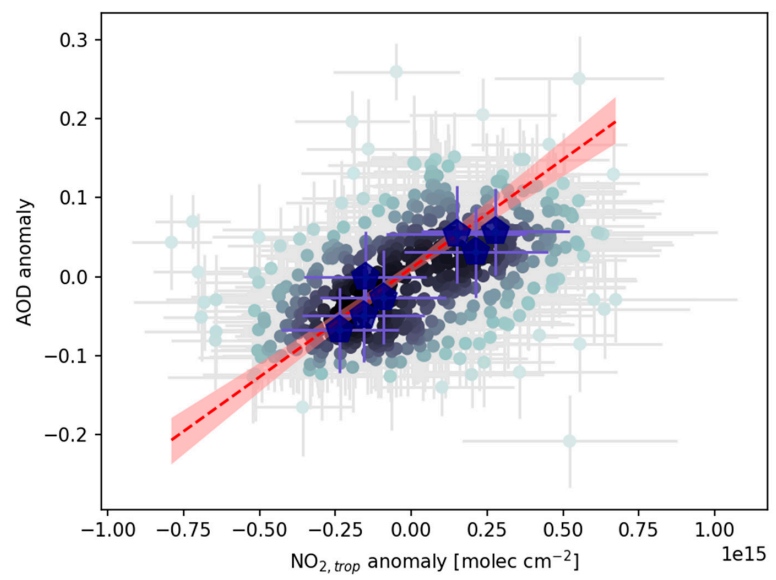

Figure 3. Summertime (JJA) anomalies of $\mathrm{AOD}$ vs. tropospheric $\mathrm{NO}_{2}$ column densities over the southeastern USA for the years 2005-2011. Blue pentagons represent averages over the whole domain $(r=0.92)$ while the dots represent $1^{\circ} \times 1^{\circ}$ degree pixels within the domain. AOD is from L3 AATSR and tropospheric $\mathrm{NO}_{2}$ from L3 OMI. The error bars represent the uncertainty of the observations (one standard deviation). The linear fit shown with the red dashed line is based on the individual data points $\left(A O D_{\text {anom }}=2.56 e^{-16}\left( \pm 2.74 e^{-17}\right) N O_{2, \text { trop, anom }}+0.005( \pm 0.006), 574\right.$ observations, $r=0.43$, with $95 \%$ confidence intervals given in the parenthesis). The red curtain represents the $95 \%$ confidence interval for the linear fit. The colour of the dots indicates the density of the overlapping data points: the darker the colour, the more overlapping points there are.

The regression analysis showed that in addition to the tropospheric $\mathrm{NO}_{2}$ column density anomalies only LST anomalies and southerly wind speeds (SW10) exhibited linear relationships with AOD. We confirmed with regression analysis that these quantities were not correlated with each other and used them as independent parameters in the analysis. To quantify the relation between $\mathrm{AOD}$ and these parameters, we calculated a multivariate fit to the data and obtained the following equation (with $95 \%$ confidence intervals given in parenthesis):

$$
A O D_{\text {anom }}=a N O_{2, \text { trop,anom }}+b L S T_{\text {anom }}+c S W V 10_{\text {anom }}+d,
$$

where

$$
\begin{aligned}
& a=2.68 \mathrm{e}^{-16} \pm 2.87 \mathrm{e}^{-17} \mathrm{~cm}^{2} \text { molec }^{-1}, \\
& b=0.007 \pm 0.006 \mathrm{~K}^{-1}, \\
& c=0.032 \pm 0.019 \mathrm{~s} \mathrm{~m}^{-1}, \text { and } \\
& d=-0.003 \pm 0.006 .
\end{aligned}
$$

The dependence of AOD on the tropospheric $\mathrm{NO}_{2}$ column density anomalies and LST anomalies was expected as they are proxies for anthropogenic and biogenic emissions, respectively, which are known to influence AOD levels [18,73]. However, the dependence of AOD on SW10 was not detected from our earlier analysis with the domain averages (Figure 1) as it was likely hidden by the spatial averaging. Nevertheless, a wind speed dependence on aerosol concentrations is to be expected as it can be caused both by transport of aerosols generated elsewhere to the studied area as well as by transport of aerosols away and thus reducing the aerosol load with higher wind speeds. To investigate this effect of wind speed on the observed AOD we used our CONTROL simulation to see which quantities were correlated with meridional wind speeds (V10). For the analysis, we calculated summer averages for all the grid cells in the southeastern USA for the summers 2002-2010. Based on this dataset, none of the meteorological variables (relative humidity, vertically integrated water vapour, and tropopause height) exhibited a linear relationship with V10. Then we looked at the AODs of different aerosol species and found that only the AODs of sea salt and dust aerosols were positively correlated with V10. The correlation coefficients for sea salt and dust AOD were 0.58 and 0.33 , respectively. To evaluate the significance of these species regarding the total $\mathrm{AOD}$, we calculated their fraction 
from the total AOD and found that the correlation coefficients between these fractions and V10 were even higher: 0.70 and 0.45 for sea salt and dust, respectively. These results indicate that the dependence of AOD on SW10 is most likely caused by the transport of sea salt and dust aerosol to the region. The dust aerosols are likely transported long-range from the Sahara [82].

Although the observations indicate that the temperature-dependent AOD component is likely caused by biogenic emissions, it is not possible to ascertain the cause based solely on the observations. Therefore, we used climate model simulations as described in Section 2.2, to test whether the effect of biogenic emissions on the AOD would provide a plausible explanation for the observed temperature dependence of AOD. As a first step, we calculated the contribution of different aerosol species to the summertime AOD in the southeastern USA to see which aerosol sources are the most dominant ones. Based on our CONTROL simulation the contributions from water, $\mathrm{SO}_{4}$, biogenic $\mathrm{SOA}, \mathrm{OC}$, sea salt, mineral dust, and $\mathrm{BC}$ to $\mathrm{AOD}$ are $54 \%, 27 \%, 11 \%, 3 \%, 2 \%, 1 \%$, and $1 \%$, respectively. Water is the most abundant aerosol component but as it is usually present with most aerosol types in a concentration depending on hygroscopicity and ambient relative humidity, it does not provide us information on the sources of aerosols. However, the prevalence of the other components is in line with our observational results: anthropogenic emissions $\left(\mathrm{SO}_{4}\right)$ are the dominant drivers of AOD but biogenic emissions (biogenic SOA and part of OC) have also a strong impact on AOD. Biomass burning emissions (BC and OC), and marine (sea salt) and dust sources have minor contributions to the seasonal AOD level.

Next, we estimated the contribution of biogenic aerosol by subtracting the average summertime AOD values (summers 2002-2010) of the noBIOSOA simulation from the corresponding values of the CONTROL run. As Figure 4 shows, modelled AOD of biogenic SOA has a clear temperature dependence $\left((4 \pm 1) \times 10^{-3} \mathrm{~K}^{-1}\right)$, which is within the uncertainty range of the temperature dependence of AOD obtained from the satellite observations $\left((7 \pm 6) \times 10^{-3} \mathrm{~K}^{-1}\right)$. Since BVOC emissions and the following SOA formation are temperature-dependent in the model, this may seem like a trivial result. However, the magnitude of the impact these emissions have on AOD is not predefined and it depends on atmospheric chemistry (see for example [9] for more details), state and composition. Therefore, the simulations can be used to evaluate the observational results. As the simulated and observation-based temperature dependence of AOD are in the same range, this agreement indicates that biogenic emissions could be the main cause for the temperature dependence of AOD in this region.

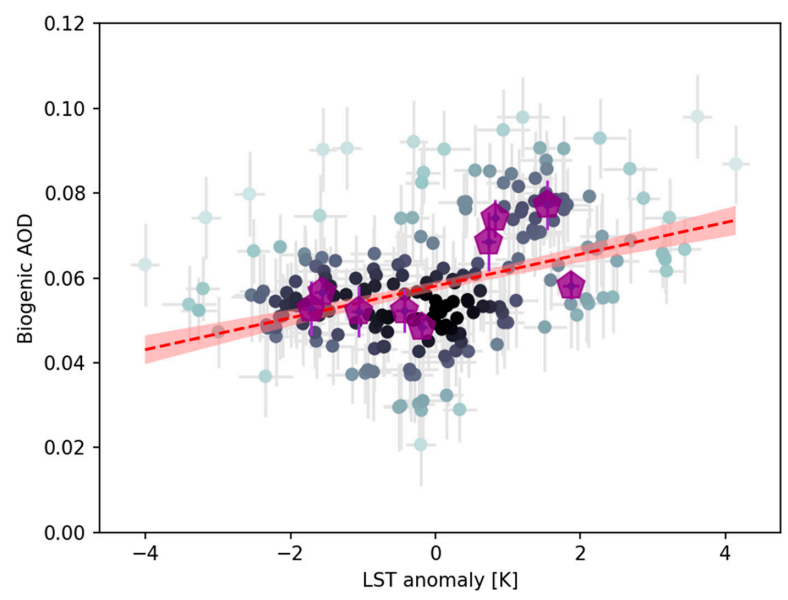

Figure 4. Biogenic AOD (based on the difference between the CONTROL and the noBIOSOA simulations) vs. LST anomaly for the summers (JJA) 2002-2010. Pentagons represent averages over the whole domain $(r=0.65)$ while the dots represent $1.9^{\circ} \times 1.9^{\circ}$ pixels within the domain. The dashed line represents the linear fit to the individual data points $\left(A O D_{b i o}=0.004( \pm 0.001) L S T_{\text {anom }}+0.058( \pm 0.002), 198\right.$ points, $r=0.38$, $95 \%$ confidence intervals given in the parenthesis), the red curtain represents the $95 \%$ confidence interval for the linear fit and the error bars represent the uncertainty caused by averaging (one standard deviation). The colour of the dots indicates the density of the overlapping data points: the darker the colour, the more overlapping points. 


\subsection{Temperature Dependence of Summertime AOD over the Most Common Land Cover Types}

The largest source of isoprene emissions in the southeastern USA is broadleaf trees [57,83], thus if the observed temperature dependence of AOD is caused by biogenic emissions the dependence should be larger in the vicinity of forests than in locations with fewer trees. To study this, we used the MODIS land cover type classification data and limited the observed datasets to the three most common land cover types: woody savannas (22 pixels out of 82 ), mixed forests (13 pixels out of 82 ) and cropland/natural mosaic (10 pixels out of 82) (see Figure S6 for details). Then, the same analysis we did to estimate the temperature-dependent AOD component for the whole domain (described in Section 3.1) was also performed for each of the land cover types separately. None of the three land cover types exhibited a distinguishable relationship between AOD and LST anomalies (see Figures S7-S9 for details) whereas AOD and tropospheric $\mathrm{NO}_{2}$ column density anomalies exhibited positive linear relationships over all of them (see Figures S10-S12 for details). The ODR analysis revealed that over mixed forests AOD was related to tropospheric $\mathrm{NO}_{2}$ column density anomalies and temperature anomalies but not to southerly wind speed anomalies (with $95 \%$ confidence intervals given in parentheses):

$$
A O D_{\text {anom }, M F}=a N O_{2, \text { trop,anom }}+b L_{\text {anom }}+c S W V 1 T_{\text {anom }}+d,
$$

where

$$
\begin{aligned}
& a=2.07 \mathrm{e}^{-16} \pm 5.11 \mathrm{e}^{-17} \mathrm{~cm}^{2} \mathrm{molec}^{-1}, \\
& b=0.027 \pm 0.013 \mathrm{~K}^{-1}, \\
& c=0.022 \pm 0.041 \mathrm{~s} \mathrm{~m}^{-1}, \text { and } \\
& d=0.001 \pm 0.012
\end{aligned}
$$

Over woody savannas AOD was related to tropospheric $\mathrm{NO}_{2}$ column density anomalies and southerly wind speed anomalies but not to temperature anomalies:

$$
A O D_{\text {anom }, W S}=a N O_{2, \text { trop,anom }}+b S S T_{\text {anom }}+c S W V 10_{\text {anom }}+d,
$$

where

$$
\begin{aligned}
& a=2.07 \mathrm{e}^{-16} \pm 4.94 \mathrm{e}^{-17} \mathrm{~cm}^{2} \text { molec}^{-1}, \\
& b=-0.005 \pm 0.011 \mathrm{~K}^{-1}, \\
& c=0.056 \pm 0.033 \mathrm{~s} \mathrm{~m}^{-1}, \text { and } \\
& d=-0.000 \pm 0.012 .
\end{aligned}
$$

Over cropland/natural mosaic AOD was clearly related only to tropospheric $\mathrm{NO}_{2}$ column density anomalies:

$$
A O D_{\text {anom }, C M}=a N O_{2, \text { trop,anom }}+b L_{\text {anom }} \mp c S W V 10_{\text {anom }}+d,
$$

where

$$
\begin{aligned}
& a=2.25 \mathrm{e}^{-16} \pm 5.12 \mathrm{e}^{-17} \mathrm{~cm}^{2} \text { molec }^{-1}, \\
& b=0.003 \pm 0.010 \mathrm{~K}^{-1}, \\
& c=-0.016 \pm 0.033 \mathrm{~s} \mathrm{~m}^{-1}, \text { and } \\
& d=-0.000 \pm 0.013 .
\end{aligned}
$$

These regression results indicate that the positive temperature dependence of AOD was statistically significant only over mixed forests where the AOD increases as a function of temperature by approximately $(27 \pm 13) \times 10^{-3} \mathrm{~K}^{-1}$. The slope of this linear fit is almost four times larger than that for the whole domain. This is in line with the notion that forests are the main BVOC source in the studied domain $[57,83]$. As the other land cover types are emitting significantly smaller amounts of BVOCs, this finding supports our assumption that the temperature-dependent AOD component derived from the observations is most likely caused by SOA formed from biogenic VOC emissions. Furthermore, 
AOD depends on southerly wind speed anomalies only over woody savannas, which are mainly located at the southeastern corner of the southeastern USA close to the coasts (see Figure S6 for details), which is a region most likely affected by transport of sea salt and Saharan dust. Finally, the AODs over all land cover types exhibited a clear dependence on tropospheric $\mathrm{NO}_{2}$ column density anomalies, which underlines the significance of anthropogenic emissions on AOD levels in this region.

\subsection{Radiative Impacts}

In order to estimate the climate effect of the temperature-dependent AOD (or biogenic) component in the southeastern USA, the regional direct radiative effects (DRE) were calculated from the observations and the simulations. For the measurement-based estimate, the linear regression fit between the AOD and temperature anomalies (see Equation (1)) was used. The slope of $(7 \pm 6) \times 10^{-3} \mathrm{~K}^{-1}$ represents our best estimate with $95 \%$ confidence. Using this AOD change per temperature degree in the following equation, we estimated the regional DRE of the temperature-dependent AOD component (e.g., [84]):

$$
D R E=S_{\text {rad }} \varphi A O D\left(1-C_{c}\right) T_{a t m}^{2}\left(1-R_{s}\right)^{2}\left(2 R_{s} \frac{1-\omega}{\left(1-R_{s}\right)^{2}}-\beta \omega\right)
$$

where $S_{\text {rad }}$ is the incident solar radiation $\left(461 \mathrm{~W} / \mathrm{m}^{2}\right)$ at the top of the atmosphere integrated over the 24-h day, $\phi$ is the mean daytime value of the secant of the solar zenith angle (1.33), $C_{c}$ is the fractional cloud amount ( 0.0 for clear-sky and 0.6 for all-sky), $T_{a t m}$ is the aerosol-free atmospheric transmission (0.76), $R_{s}$ is the shortwave surface reflectance (0.15), $\omega$ is the single scattering albedo (0.972), and $\beta$ is the up-scatter fraction (0.21). All values used in the equation, except for $S_{\text {rad }}$ and $\phi$, were taken from Goldstein et al. [18]. The region and season averaged $S_{\text {rad }}$ and $\phi$ were calculated with the help of the tools in the LibRadtran package [85]. The original equation by Haywood and Shine [84] was designed for global DRE estimates and it includes the global variables day length and solar constant, thus the equation was modified for regional calculations by replacing them with $S_{\text {rad }}$ and $\phi$ to get a regional DRE estimate. Using these assumptions, the measurement-based DRE estimates for the whole domain are $-0.33 \pm 0.29 \mathrm{~W} / \mathrm{m}^{2} / \mathrm{K}$ and $-0.13 \pm 0.11 \mathrm{~W} / \mathrm{m}^{2} / \mathrm{K}$ for clear- and all-sky conditions, respectively. For the mixed forest pixels, the corresponding DRE estimates are $-1.3 \pm 0.7 \mathrm{~W} / \mathrm{m}^{2} / \mathrm{K}$ and $-0.5 \pm 0.3 \mathrm{~W} / \mathrm{m}^{2} / \mathrm{K}$ for clear- and all-sky conditions, respectively.

We also estimated the summertime clear-sky DRE of biogenic aerosols from the model simulations by calculating the difference between the net clear sky top-of-atmosphere solar radiation from the CONTROL and the noBIOSOA simulations as a function of temperature anomalies. A linear fit to the dataset produced the following function: $D R E_{\text {bio }}=-0.29( \pm 0.09) L S T_{\text {ano }}-1.59( \pm 0.11)$ (see Figure $S 13$ for details). Thus, a one Kelvin increase in temperature corresponds to a biogenic DRE of $-0.29 \pm 0.09 \mathrm{~W} / \mathrm{m}^{2}$ and so the model-based clear-sky DRE estimate is in a very good agreement with the observation-based estimate for the whole domain.

Paasonen et al. [15] analysed long-term observations of aerosol particles and biogenic vapors in continental mid- and high-latitude environments. Their results showed that aerosol cooling effects are strengthened by increasing biogenic vapour emissions in warmer temperatures. When compared with the DRE estimates presented by Paasonen et al. [15] for several locations across Europe, our DRE estimates for the southeastern USA are more negative. For the growth season $\left(\mathrm{T}>5^{\circ} \mathrm{C}\right)$ Paasonen et al. [15] reported a DRE average of $-0.03(-0.060-0.006) \mathrm{W} / \mathrm{m}^{2} / \mathrm{K}$. Thus, our regional DRE estimates are five times larger than their maximum estimate and our DRE estimate for the mixed forests is over 20 times larger. Furthermore, Lihavainen et al. [86] estimated the DRE for the Pallas-Sodankylä Global Atmosphere Watch (GAW) station in Northern Finland with two methods: ground-based remote sensing and in-situ observations. Both methods produced similar estimates $\left(-0.097 \pm 0.066 \mathrm{~W} / \mathrm{m}^{2} / \mathrm{K}\right.$ and $-0.063 \pm 0.040 \mathrm{~W} / \mathrm{m}^{2} / \mathrm{K}$ with remote sensing and in situ observations, respectively), which are three to five times smaller than our estimates for the southeastern USA. This difference in the magnitude of the estimates is in line with the findings of Xu et al. [23] and Carlton and Turpin [87], who showed that the biogenic SOA mass concentrations are 
high in the southeastern USA because the particle partitioning potential of organic compounds is driven by anthropogenic pollution. Consequently, high levels of pollution enhance the formation of biogenic SOA, which leads to more pronounced radiative effects of biogenic aerosols over the southeastern USA than in regions with less pollution (e.g., boreal forests).

Based on an equation similar to Equation (5) and AOD observations done with MISR, Goldstein et al. [18] estimated that the all-sky DRE of the summertime aerosols in this region would be $-3.9 \mathrm{~W} / \mathrm{m}^{2}$ (although they erroneously called it clear-sky). They estimated the radiative effect as the difference between summertime and wintertime AODs (resulting in an AOD difference of 0.18). For the clear-sky case $\left(C_{c}=0\right)$ their DRE estimate would be $-9.75 \mathrm{~W} / \mathrm{m}^{2}$. For comparison, we calculated seasonal differences (summer-winter (DJF) averages) from our datasets. Based on the AATSR data, the seasonal AOD difference was 0.23, which is in the same range as the seasonal AOD difference reported by Goldstein et al. [18]. To compare how much the non-anthropogenic AOD could change due to the seasonal temperature difference we calculated the seasonal temperature difference $(17.5 \mathrm{~K})$ and multiplied it with the slope of the temperature dependence of the AOD $\left((7 \pm 6) \times 10^{-3} \mathrm{~K}^{-1}\right)$, resulting in an AOD change of $0.12 \pm 0.10$. This is only half of the total seasonal AOD difference. Assuming that our equation correctly represents the biogenic contribution to the AOD for the seasonal temperature range, this implies that the difference between the winter and summertime AODs cannot solely be explained with biogenic emissions.

In a similar way, we estimated that the DRE of the temperature dependent AOD component due to the seasonal temperature change would be $-6.0 \pm 4.7 \mathrm{~W} / \mathrm{m}^{2}$ and $-2.4 \pm 1.9 \mathrm{~W} / \mathrm{m}^{2}$ for clear- and all-sky conditions, respectively. Furthermore, we estimated the clear-sky DRE caused by biogenic aerosols from the model simulations by subtracting the summertime net clear sky top-of-atmosphere solar radiation of the noBIOSOA simulation from the CONTROL simulation. This led to an average clear-sky DRE of $-1.9 \pm 0.7 \mathrm{~W} / \mathrm{m}^{2}$, which is at the lower limit of our observational estimate for the clear sky DRE of the temperature-dependent AOD component and significantly smaller than the DRE estimate of Goldstein et al. [18]. This supports our previous conclusion that there are other factors in addition to the temperature-enhanced biogenic emissions that affect the seasonal AOD difference in this region and the radiative effects of biogenic aerosols cannot be estimated based on seasonal differences in the aerosol load. To highlight the importance of anthropogenic emissions on the seasonal AOD differences we calculated the following example. During the years 2005-2007 when the summertime tropospheric $\mathrm{NO}_{2}$ column densities were larger than $2.3 \times 10^{15}$ molecules $/ \mathrm{cm}^{2}$, the seasonal AOD difference was 0.27. For the summers 2008-2011 with tropospheric $\mathrm{NO}_{2}$ column densities lower than $2.3 \times 10^{15}$ molecules $/ \mathrm{cm}^{2}$, the seasonal AOD difference was also lower, 0.20 . However, for both periods the temperature change between the seasons was equivalent: $17.4 \mathrm{~K}$ and 17.8 K for 2005-2007 and 2008-2011, respectively. The significantly larger AOD difference corresponds to larger tropospheric $\mathrm{NO}_{2}$ column densities while the temperature change does not seem to have a noticeable effect. Furthermore, when the seasonal AOD differences from the years 2005-2011 are compared with annual averages of tropospheric $\mathrm{NO}_{2}$ column densities there is a clear linear relationship with positive correlation $\left(r^{2}=0.93\right)$. Therefore, it appears that anthropogenic emissions have a more dominant role than biogenic emissions in the seasonal change of AOD, although the biogenic emissions are a prerequisite for the process.

Attwood et al. [24] estimated that between 2001 and 2013 the summertime surface radiative effect decreased by $8.0 \mathrm{Wm}^{-2}$ in the southeastern USA. Their estimate was based on aircraft measurements and radiative transfer modelling. To see whether our datasets produced corresponding results, we did a similar calculation using the difference between the summertime averages of AATSR AOD from the years 2005 and 2011 in Equation (5). Between these years, the AOD decreased by 0.06 and the DRE decreased by $2.9 \mathrm{Wm}^{-2}$. This is only $36 \%$ of the estimate by Attwood et al. [24]. Attwood et al. [24] had also included a time series of MISR AOD in the supplementary materials for their paper, and from this figure we estimated that the summertime AOD had decreased from 0.275 to 0.188 between 2001 and 2013. Using this change of AOD in Equation (5), we calculated the corresponding decrease in DRE 
to be $4.3 \mathrm{Wm}^{-2}$, which is closer to our AATSR estimate $\left(2.9 \mathrm{Wm}^{-2}\right)$ and only half of that reported by Attwood et al. [24]. As the AOD-based estimates of DRE decrease are in the same range but much lower than the reported decrease of $8.0 \mathrm{Wm}^{-2}$, it may be that the reported value of Attwood et al. [24] is an overestimate.

As the DRE estimates showed, biogenic SOA has a significant direct radiative effect on a regional scale and especially over forests. To estimate its indirect radiative effects, we used the model data to approximate the effective radiative forcing (ERF). ERF includes the rapid tropospheric adjustments (often related to humidity and clouds) to the radiative forcing. ERF was calculated from the difference of the summed net top-of-atmosphere solar and thermal radiation from the CONTROL and the noBIOSOA simulations as a function of temperature anomalies. A linear fit to the dataset produced the following function: $\mathrm{ERF}_{\text {bio }}=-1.05( \pm 0.46) \mathrm{LST}_{\mathrm{ano}}+0.80( \pm 0.53)$ (see Figure S14 for details). Thus, a one Kelvin increase in temperature corresponds to a biogenic ERF of $-1.0 \pm 0.5 \mathrm{~W} / \mathrm{m}^{2}$. Paasonen et al. [15] reported an average cloud albedo effect (first indirect effect) for the growth season $\left(\mathrm{T}>5^{\circ} \mathrm{C}\right)$ at several locations across Europe to be $-0.19(-0.76-0.06) \mathrm{W} / \mathrm{m}^{2} / \mathrm{K}$. Our estimate for the southeastern USA is five times larger than the European average, but our maximum estimate is only about $60 \%$ larger than the European maximum. This indicates that biogenic SOA has also a significant indirect radiative effect in the studied region.

\section{Conclusions}

By using satellite remote sensing observations from AATSR and OMI and aerosol-climate model ECHAM-HAMMOZ simulations in concert, we quantified the observed temperature dependence of the AOD and the corresponding radiative effects over the southeastern USA. The satellite observations lead to the conclusion that anthropogenic emissions are the main driver of summertime AOD levels in this region. There is also a temperature-dependent component in the summertime AOD over the southeastern USA but its impact on the total AOD is considerably smaller than the impact of anthropogenic emissions and, therefore, it is not clearly visible due to the changing level of anthropogenic emissions. Furthermore, it appears that anthropogenic emissions have a more dominant role in the seasonal cycle of AOD than biogenic emissions, although biogenic emissions are a prerequisite for the cycle.

To quantify the temperature-dependent AOD component, we used the Orthogonal Distance Regression method. Based on this analysis, AOD appears to be influenced by tropospheric $\mathrm{NO}_{2}$ column densities, LST and southerly wind speed but not by the other parameters used in our analysis. The dependence on tropospheric $\mathrm{NO}_{2}$ column densities could be explained by anthropogenic emissions, whereas the dependence on southerly wind speed is likely a result of transported sea salt and Saharan dust. This analysis shows that the AOD has a small dependence on temperature $\left((7 \pm 6) \times 10^{-3} \mathrm{~K}^{-1}\right)$. Our model simulations produced a similar temperature dependence of the biogenic AOD over the southeastern USA. The model showed that the increase in AOD due to BVOC emissions and the subsequent SOA formation was $(4 \pm 1) \times 10^{-3} \mathrm{~K}^{-1}$, which is within the uncertainty range of the observed change in the temperature-dependent AOD component.

To evaluate the effect of the vegetation type on the observed temperature dependence of AOD we used the MODIS land cover type classification. The data showed that the three most abundant land cover types in this region are woody savannas, mixed forests and cropland/natural mosaic. When the analysis was limited to $1^{\circ} \times 1^{\circ}$ pixels covered mainly with the above mentioned land cover types, only pixels with mixed forests exhibited a clear temperature dependence of the AOD. For the pixels covered mainly by mixed forests the biogenic contribution increases non-anthropogenic AOD by approximately $(31 \pm 13) \times 10^{-3} \mathrm{~K}^{-1}$, which is over four times larger than for the whole domain. As the largest source of isoprene emissions in the southeastern USA are broadleaf trees [57,83], the increased temperature dependence of AOD in the vicinity of forests supports our assumption that the temperature dependence is most likely caused by SOA formed from biogenic VOC emissions that increase with increasing temperature. 
The corresponding clear-sky direct radiative effect (DRE) of the observation-based biogenic AOD is $-0.33 \pm 0.29 \mathrm{~W} / \mathrm{m}^{2} / \mathrm{K}$ and $-1.3 \pm 0.7 \mathrm{~W} / \mathrm{m}^{2} / \mathrm{K}$ for the whole domain and over mixed forests only, respectively. The model estimate of the regional clear-sky DRE for biogenic aerosols is in the same range as the observational estimate: $-0.29 \pm 0.09 \mathrm{~W} / \mathrm{m}^{2} / \mathrm{K}$. All these DRE values are significantly larger than the values reported for other forested regions $[15,86]$. Most likely, the more pronounced radiative effects of biogenic aerosols over the southeastern USA are caused by high levels of pollution that enhance the formation of biogenic SOA. Furthermore, the model simulations show that biogenic emissions have a significant effect on the indirect radiative forcing in this region. The approximated effective radiative forcing (ERF) for the biogenic aerosols was $-1.0 \pm 0.5 \mathrm{~W} / \mathrm{m}^{2} / \mathrm{K}$, which is larger than the values reported for other forested regions [15].

Supplementary Materials: The following are available online at http:/ /www.mdpi.com/2073-4433/9/5/180/s1, Figure S1: Time series of monthly averaged AOD over the southeastern US from AATSR and MISR Level 3 products for the years 2003-2011, Figure S2: Monthly averaged Level 3 MISR AOD vs. Level 3 AATSR AOD over the southeastern US for the years 2003-2011, Figure S3: Summertime averaged tropospheric $\mathrm{NO}_{2}$ column densities vs. sulfate particle mass (diameter below $2.5 \mu \mathrm{m}$ ) in the southeastern US for the years 2005-2011, Figure S4: Monthly mean observed LST vs. simulated LST in the southeastern US for the years 2002-2010, Figure S5: Monthly mean observed AOD vs. simulated AOD over the southeastern US for the years 2002-2010, Figure S6: The most common vegetation types in the southeastern US based on the MODIS MCD12C1 product for the year 2011, Figure S7: Summertime anomalies (JJA) of aerosol optical depth (AOD) vs. regional mean land surface temperature (LST) over mixed forests in the southeastern US for the years 2005-2011, Figure S8: Summertime anomalies (JJA) of aerosol optical depth (AOD) vs. regional mean land surface temperature (LST) over woody savannas in the southeastern US for the years 2005-2011, Figure S9: Summertime anomalies (JJA) of aerosol optical depth (AOD) vs. regional mean land surface temperature (LST) over cropland/natural mosaic in the southeastern US for the years 2005-2011, Figure S10: Summertime (JJA) anomalies of AOD vs. tropospheric $\mathrm{NO}_{2}$ column densities over mixed forests in the southeastern US for the years 2005-2011, Figure S11: Summertime (JJA) anomalies of AOD vs. tropospheric $\mathrm{NO}_{2}$ column densities over woody savannas in the southeastern US for the years 2005-2011, Figure S12: Summertime (JJA) anomalies of $\mathrm{AOD}$ vs. tropospheric $\mathrm{NO}_{2}$ column densities over cropland/natural mosaic in the southeastern US for the years 2005-2011, Figure S13: Biogenic aerosol direct radiative effect (DRE, based on the difference between the CONTROL and the noBIOSOA simulations) vs. LST anomaly for the summers (JJA) 2002-2010, Figure S14: Effective radiative forcing caused by biogenic emissions (ERF, based on the difference between the CONTROL and the noBIOSOA simulations) vs. LST anomaly for the summers (JJA) 2002-2010, Table S1: Satellite product used in the evaluation of the AATSR AOD product., Table S2: Summer and annual averages of land surface temperature (LST), aerosol optical depth (AOD) and tropospheric $\mathrm{NO}_{2}$ concentrations (NO2trop) based on AATSR and OMI observations over the southeastern US.

Author Contributions: T.M., Harri Kokkola, A.A., Hannele Korhonen and G.d.L. conceived and designed the study; T.M., A.H., T.K., J.M., T.B., Hannele Korhonen and Harri Kokkola performed the simulations and analyzed the data; T.M., P.K., L.S., D.G., A.L., M.P., A.A. and G.d.L. gathered and combined the satellite products and analyzed the data; all the authors contributed to discussion and the writing/editing of the manuscript.

Acknowledgments: This work was funded by the ESA Living Planet Fellowship (ESA contract No. 4000112802/14/I-SBo), the Academy of Finland Centre of Excellence in Atmospheric Science (272041), Academy Research Fellowship $(250348,256208)$ and Academy project RECIA (287440), ERC Consolidator Grant ECLAIR (646857), the Nordic Center of Excellence eSTICC (sScience Tool for Investigating Climate Change in northern high latitudes) funded by Nordforsk (grant 57001), and the European Union's Horizon 2020 research and innovation programme under grant agreement No 641816 Coordinated Research in Earth Systems and Climate: Experiments, kNowledge, Dissemination and Outreach (CRESCENDO).We acknowledge the OMI mission scientists and associated NASA personnel for the production of the data used in this research, the ESA Climate Change Initiative and in particular the Aerosol_cci project for providing the AOD data from AATSR. The ATSR GlobTemperature Level-2/Level-3 v1.0 LST data were made available through the GlobTemperature Data Portal and were generated through the ESA DUE GlobTemperature Project with the support of NCEO. The ECHAM-HAMMOZ model is developed by a consortium composed of ETH Zurich, Max Planck Institut für Meteorologie, Forschungszentrum Jülich, University of Oxford, the Finnish Meteorological Institute, and the Leibniz Institute for Tropospheric Research and managed by the Center for Climate Systems Modeling (C2SM) at ETH Zurich. IMPROVE is a collaborative association of state, tribal, and federal agencies, and international partners. US Environmental Protection Agency is the primary funding source, with contracting and research support from the National Park Service. The Air Quality Group at the University of California, Davis is the central analytical laboratory, with ion analysis provided by Research Triangle Institute, and carbon analysis provided by Desert Research Institute.

Conflicts of Interest: The authors declare no conflict of interest. 


\section{Abbreviations}

The following abbreviations and acronyms are used in this manuscript:

$\beta \quad$ Up-scatter fraction

$\phi \quad$ Mean daytime value of the secant of the solar zenith angle

$\omega \quad$ Single scattering albedo

AATSR Advanced Along-Track Scanning Radiometer

ACCMIP Atmospheric Chemistry and Climate model Intercomparison Project

ADV AATSR Dual-View algorithm

AOD Aerosol optical depth

BENZ Benzene

BVOC Biogenic volatile organic compounds

$\mathrm{C}_{c} \quad$ Fractional cloud amount

CCI Climate change initiative

CCN Cloud condensation nuclei

CMG Climate Modelling Grid

CONTROL Simulation with all model schemes in use

DJF December-January-February

DRE Direct radiative effect

DUE Data User Element

$E_{a} \quad$ Activation enthalpy

ENVISAT Environmental satellite

ERF Effective radiative forcing

ESA European Space Agency

ECMWF European Centre for Medium-Range Weather Forecasts

GAW Global Atmosphere Watch

GFED Global Fire Emissions Database

GISS Goddard Institute for Space Studies

GLYX Glyoxals

IEPOX Isoprene epoxydiols

IGBP International Geosphere Biosphere Programme

IMPROVE Interagency Monitoring of PROtected Visual Environments

ISOP Isoprene

JJA June-July-August

$k \quad$ Reaction coefficient for VOC oxidation

$k_{0} \quad$ Reference reaction coefficient

LST Land surface temperature

MEGAN Model of Emissions of Gases and Aerosols from Nature

MISR Multi-angle Imaging SpectroRadiometer

MODIS Moderate Resolution Imaging Spectroradiometer

MTP Monoterpenes

NASA GES National Aeronautics and Space Administration Goddard Earth

DISC Sciences Data and Information Services Center

noBIOSOA Simulation without biogenic SOA precursor emissions

ODR Orthogonal Distance Regression

OMI Ozone Monitoring Instrument

POM Primary organic matter

$R \quad$ Gas constant

$\mathrm{r} \quad$ Correlation coefficient

$R_{S} \quad$ Shortwave surface reflectance

RMSE Root-mean-square error

$S_{\text {rad }} \quad$ Incident solar radiation at the top of the atmosphere

SALSA Sectional Aerosol module for Large-Scale Applications

SOA Secondary organic aerosol

SW10 Southerly wind speed

$T \quad$ Temperature

$T_{\text {atm }} \quad$ Aerosol-free atmospheric transmission

TOA Top-of-the-atmosphere

TOL Toluene

U10 Wind speed component (east-west direction) at $10 \mathrm{~m}$ altitude

US United States

V10 Wind speed component (north-south direction) at $10 \mathrm{~m}$ altitude

VBS Volatility basis set

VOC Volatile organic compounds

XYL Xylene 


\section{References}

1. Charlson, R.J.; Schwartz, S.E.; Hales, J.M.; Cess, R.D.; Coakley, J.A., Jr.; Hansen, J.E.; Hormann, D.J. Climate forcing by anthropogenic aerosols. Science 1992, 255, 423-430. [CrossRef] [PubMed]

2. Albrecht, B.A. Aerosols, Cloud Microphysics, and Fractional Cloudiness. Science 1989, 245, 1227-1230. [CrossRef] [PubMed]

3. Twomey, S. Aerosols, clouds, and radiation. Atmos. Environ. 1991, 25, 2435-2442. [CrossRef]

4. Stevens, B.; Feingold, G. Untangling aerosol effects on clouds and precipitation in a buffered system. Nature 2009, 461, 607. [CrossRef] [PubMed]

5. International Panel on Climate Change. Climate Change 2013: The Physical Science Basis. In Contribution of Working Group I to the Fifth Assessment Report of the Intergovernmental Panel on Climate Change; Stocker, T.F., Qin, D., Plattner, G.-K., Tignor, M., Allen, S.K., Boschung, J., Nauels, A., Xia, Y., Bex, V., Midgley, P.M., Eds.; Cambridge University Press: Cambridge, UK; New York, NY, USA, 2013; pp. 1-1535.

6. Carslaw, K.S.; Lee, L.A.; Reddington, C.L.; Pringle, K.J.; Rap, A.; Forster, P.M.; Mann, G.W.; Spracklen, D.V.; Woodhouse, M.T.; Regayre, L.A.; et al. Large contribution of natural aerosols to uncertainty in indirect forcing. Nature 2013, 503, 67-71. [CrossRef] [PubMed]

7. Goldstein, A.H.; Galbally, I.E. Known and Unexplored Organic Constituents in the Earth's Atmosphere. Environ. Sci. Technol. 2007, 41, 1514-1521. [CrossRef] [PubMed]

8. Donahue, N.M.; Robinson, A.L.; Stanier, C.O.; Pandis, S.N. Coupled Partitioning, Dilution, and Chemical Aging of Semivolatile Organics. Environ. Sci. Technol. 2006, 40, 2635-2643. [CrossRef] [PubMed]

9. Scott, C.E.; Rap, A.; Spracklen, D.V.; Forster, P.M.; Carslaw, K.S.; Mann, G.W.; Pringle, K.J.; Kivekäs, N.; Kulmala, M.; Lihavainen, H.; et al. The direct and indirect radiative effects of biogenic secondary organic aerosol. Atmos. Chem. Phys. 2014, 14, 447-470. [CrossRef]

10. Duncan, B.N.; Yoshida, Y.; Damon, M.R.; Douglass, A.R.; Witte, J.C. Temperature dependence of factors controlling isoprene emissions. Geophys. Res. Lett. 2009, 36, L05813. [CrossRef]

11. Penuelas, J.; Staudt, M. BVOCs and global change. Trends Plant Sci. 2010, 15, 133-144. [CrossRef] [PubMed]

12. Stavrakou, T.; Müller, J.-F.; Bauwens, M.; De Smedt, I.; Van Roozendael, M.; De Mazière, M.; Vigouroux, C.; Hendrick, F.; George, M.; Clerbaux, C.; et al. How consistent are top-down hydrocarbon emissions based on formaldehyde observations from GOME-2 and OMI? Atmos. Chem. Phys. 2015, 15, 11861-11884. [CrossRef]

13. Bauwens, M.; Stavrakou, T.; Müller, J.-F.; De Smedt, I.; Van Roozendael, M.; van der Werf, G.R.; Wiedinmyer, C.; Kaiser, J.W.; Sindelarova, K.; Guenther, A. Nine years of global hydrocarbon emissions based on source inversion of OMI formaldehyde observations. Atmos. Chem. Phys. 2016, 16, 10133-10158. [CrossRef]

14. Leaitch, W.R.; Macdonald, A.M.; Brickell, P.C.; Liggio, J.; Siostedt, S.L.; Vlasenko, A.; Bottenheim, J.W.; Huang, L.; Li, S.; Liu, S.K.; et al. Temperature response of the submicron organic aerosol from temperate forests. Atmos. Environ. 2011, 45, 6696-6704. [CrossRef]

15. Paasonen, P.; Asmi, A.; Petäjä, T.; Kajos, M.K.; Aijala, M.; Junninen, H.; Holst, T.; Abbatt, J.P.D.; Arneth, A.; Birmili, W.; et al. Warming-induced increase in aerosol number concentration likely to moderate climate change. Nat. Geosci. 2013, 6, 438-442. [CrossRef]

16. Zhang, X.; Liu, Z.; Hecobian, A.; Zheng, M.; Frank, N.H.; Edgerton, E.S.; Weber, R.J. Spatial and seasonal variations of fine particle water-soluble organic carbon (WSOC) over the southeastern United States: Implications for secondary organic aerosol formation. Atmos. Chem. Phys. 2012, 12, 6593-6607. [CrossRef]

17. Slowik, J.G.; Stroud, C.; Bottenheim, J.W.; Brickell, P.C.; Chang, R.Y.-W.; Liggio, J.; Makar, P.A.; Martin, R.V.; Moran, M.D.; Shantz, N.C.; et al. Characterization of a large biogenic secondary organic aerosol event from eastern Canadian forests. Atmos. Chem. Phys. 2010, 10, 2825-2845. [CrossRef]

18. Goldstein, A.H.; Koven, C.D.; Heald, C.L.; Fung, I. Biogenic Carbon and Anthropogenic Pollutants Combine to Form a Cooling Haze over the Southeastern US. Proc. Natl. Acad. Sci. USA 2009, 106, 8835-8840. [CrossRef] [PubMed]

19. Rattanavaraha, W.; Chu, K.; Budisulistiorini, S.H.; Riva, M.; Lin, Y.-H.; Edgerton, E.S.; Baumann, K.; Shaw, S.L.; Guo, H.; King, L.; et al. Assessing the impact of anthropogenic pollution on isoprene-derived secondary organic aerosol formation in $\mathrm{PM}_{2.5}$ collected from the Birmingham, Alabama, ground site during the 2013 Southern Oxidant and Aerosol Study. Atmos. Chem. Phys. 2016, 16, 4897-4914. [CrossRef] 
20. Budisulistiorini, S.H.; Li, X.; Bairai, S.T.; Renfro, J.; Liu, Y.; Liu, Y.J.; McKinney, K.A.; Martin, S.T.; McNeill, V.F.; Pye, H.O.T.; et al. Examining the effects of anthropogenic emissions on isoprene-derived secondary organic aerosol formation during the 2013 Southern Oxidant and Aerosol Study (SOAS) at the Look Rock, Tennessee ground site. Atmos. Chem. Phys. 2015, 15, 8871-8888. [CrossRef]

21. Kim, P.S.; Jacob, D.J.; Fisher, J.A.; Travis, K.; Yu, K.; Zhu, L.; Yantosca, R.M.; Sulprizio, M.P.; Jimenez, J.L.; Campuzano-Jost, P.; et al. Sources, seasonality, and trends of southeast US aerosol: An integrated analysis of surface, aircraft, and satellite observations with the GEOS-Chem chemical transport model. Atmos. Chem. Phys. 2015, 15, 10411-10433. [CrossRef]

22. Nguyen, T.K.V.; Capps, S.L.; Carlton, A.G. Decreasing Aerosol Water Is Consistent with OC Trends in the Southeast U.S. Environ. Sci. Technol. 2015, 49, 7843-7850. [CrossRef] [PubMed]

23. Xu, L.; Guo, H.; Boyd, C.M.; Klein, M.; Bougiatioti, A.; Cerully, K.M.; Hite, J.R.; Isaacman-VanWertz, G.; Kreisberg, N.M.; Knote, C.; et al. Effects of anthropogenic emissions on aerosol formation from isoprene and monoterpenes in the southeastern United States. Proc. Natl. Acad. Sci. USA 2015, 112, 37-42. [CrossRef] [PubMed]

24. Attwood, A.R.; Washenfelder, R.A.; Brock, C.A.; Hu, W.; Baumann, K.; Campuzano-Jost, P.; Day, D.A.; Edgerton, E.S.; Murphy, D.M.; Palm, B.B.; et al. Trends in sulfate and organic aerosol mass in the Southeast U.S.: Impact on aerosol optical depth and radiative forcing. Geophys. Res. Lett. 2014, 41, 7701-7709. [CrossRef]

25. Hidy, G.M.; Blanchard, C.L.; Baumann, K.; Edgerton, E.; Tanenbaum, S.; Shaw, S.; Knipping, E.; Tombach, I.; Jansen, J.; Walters, J. Chemical climatology of the southeastern United States, 1999-2013. Atmos. Chem. Phys. 2014, 14, 11893-11914. [CrossRef]

26. Alston, E.J.; Sokolik, I.N.; Kalashnikova, O.V. Characterization of atmospheric aerosol in the US Southeast from ground- and space-based measurements over the past decade. Atmos. Meas. Tech. 2012, 5, 1667-1682. [CrossRef]

27. Lim, H.-J.; Turpin, B.J. Origins of Primary and Secondary Organic Aerosol in Atlanta: Results of Time-Resolved Measurements during the Atlanta Supersite Experiment. Environ. Sci. Technol. 2002, 36, 4489-4496. [CrossRef] [PubMed]

28. Carrico, C.M.; Bergin, M.H.; Xu, J.; Baumann, K.; Maring, H. Urban aerosol radiative properties: Measurements during the 1999 Atlanta Supersite Experiment. J. Geophys. Res. 2003, 108, 8422. [CrossRef]

29. Holzer-Popp, T.; de Leeuw, G.; Griesfeller, J.; Martynenko, D.; Klüser, L.; Bevan, S.; Davies, W.; Ducos, F.; Deuzé, J.L.; Graigner, R.G.; et al. Aerosol retrieval experiments in the ESA Aerosol_cci project. Atmos. Meas. Tech. 2013, 6, 1919-1957. [CrossRef]

30. De Leeuw, G.; Holzer-Popp, T.; Bevan, S.; Davies, W.; Descloitres, J.; Grainger, R.G.; Griesfeller, J.; Heckel, A.; Kinne, S.; Klüser, L.; et al. Evaluation of seven European aerosol optical depth retrieval algorithms for climate analysis. Remote Sens. Environ. 2015, 162, 295-315. [CrossRef]

31. Stier, P.; Feichter, J.; Kinne, S.; Kloster, S.; Vignati, E.; Wilson, J.; Ganzeveld, L.; Tegen, I.; Werner, M.; Balkanski, Y.; et al. The aerosol-climate model ECHAM5-HAM. Atmos. Chem. Phys. 2005, 5, 1125-1156. [CrossRef]

32. Zhang, K.; O’Donnell, D.; Kazil, J.; Stier, P.; Kinne, S.; Lohmann, U.; Ferrachat, S.; Croft, B.; Quaas, J.; Wan, H.; et al. The global aerosol-climate model ECHAM-HAM, version 2: Sensitivity to improvements in process representations. Atmos. Chem. Phys. 2012, 12, 8911-8949. [CrossRef]

33. Bergman, T.; Kerminen, V.-M.; Korhonen, H.; Lehtinen, K.E.J.; Makkonen, R.; Arola, A.; Mielonen, T.; Romakkaniemi, S.; Kulmala, M.; Kokkola, H. Evaluation of the sectional aerosol microphysics module SALSA implementation in ECHAM5-HAM aerosol-climate model. Geosci. Model Dev. 2012, 5, 845-868. [CrossRef]

34. Laakso, A.; Kokkola, H.; Partanen, A.-I.; Niemeier, U.; Timmreck, C.; Lehtinen, K.E.J.; Hakkarainen, H.; Korhonen, H. Radiative and climate impacts of a large volcanic eruption during stratospheric sulfur geoengineering. Atmos. Chem. Phys. 2016, 16, 305-323. [CrossRef]

35. Kokkola, H.; Kühn, T.; Laakso, A.; Bergman, T.; Lehtinen, K.E.J.; Mielonen, T.; Arola, A.; Stadtler, S.; Korhonen, H.; Ferrachat, S.; et al. SALSA2.0: The sectional aerosol module of the aerosol-chemistry-climate model ECHAM6.3.0-HAM2.3-MOZ1.0. Geosci. Model Dev. Discuss. 2018. [CrossRef]

36. Kolmonen, P.; Sogacheva, L.; Virtanen, T.H.; de Leeuw, G.; Kulmala, M. The ADV/ASV AATSR aerosol retrieval algorithm: Current status and presentation of a full-mission AOD data set. Int. J. Digit. Earth 2016, 9, 545-561. [CrossRef] 
37. Sogacheva, L.; Kolmonen, P.; Virtanen, T.H.; Rodriguez, E.; Saponaro, G.; de Leeuw, G. Post-processing to remove residual clouds from aerosol optical depth retrieved using the Advanced Along Track Scanning Radiometer. Atmos. Meas. Tech. 2017, 10, 491-505. [CrossRef]

38. Kolmonen, P.; Sogacheva, L. Algorithm Theoretical Basis Document (ATBD) AATSR AATSR Dual View Algorithm (ADV) Version 4.2. ESA Climate Change Initiative Phase 2 Aerosol Project 2017. Available online: http:/ / www.esa-aerosol-cci.org/?q=webfm_send/1339 (accessed on 8 May 2018).

39. Prata, F. Land Surface Temperature Measurement from Space: AATSR Algorithm Theoretical Basis Document; CSIRO Atmospheric Research: Aspendale, Australia, 2002.

40. Ghent, D. Land Surface Temperature Validation and Algorithm Verification; Report to European Space Agency; European Space Agency: Paris, France, 2012.

41. Levelt, P.F.; Hilsenrath, E.; Leppelmeier, G.W.; van den Oord, G.H.J.; Bhartia, P.K.; Tamminen, J.; de Haan, J.F.; Veefkind, J.P. Science objectives of the Ozone Monitoring Instrument. IEEE Trans. Geosci. Remote Sens. 2006, 44, 1199-1208. [CrossRef]

42. Bucsela, E.J.; Krotkov, N.A.; Celarier, E.A.; Lamsal, L.N.; Swartz, W.H.; Bhartia, P.K.; Boersma, K.F.; Veefkind, J.P.; Gleason, J.F.; Pickering, K.E. A new stratospheric and tropospheric $\mathrm{NO}_{2}$ retrieval algorithm for nadir-viewing satellite instruments: Applications to OMI. Atmos. Meas. Tech. 2013, 6, 2607-2626. [CrossRef]

43. Chance, K.; Kurosu, T.P.; Rothman, L.S.; Boersma, F.; Bucsela, E.; Brinksma, E.; Gleason, J.F. OMI Algorithm Theoretical Basis Document Volume IV OMI Trace Gas Algorithms. Available online: https:/ / docserver.gesdisc.eosdis.nasa.gov/repository/Mission/OMI/3.3_ScienceDataProductDocumentation/ 3.3.4_ProductGenerationAlgorithm/ATBD-OMI-04.pdf (accessed on 8 May 2018).

44. Krotkov, N.A.; Lamsal, L.N.; Celarier, E.A.; Swartz, W.H.; Marchenko, S.V.; Bucsela, E.J.; Chan, K.L.; Wenig, M.; Zara, M. The version $3 \mathrm{OMI} \mathrm{NO}_{2}$ standard product. Atmos. Meas. Tech. 2017, 10, 3133-3149. [CrossRef]

45. Lamsal, L.N.; Krotkov, N.A.; Celarier, E.A.; Swartz, W.H.; Pickering, K.E.; Bucsela, E.J.; Gleason, J.F.; Martin, R.V.; Philip, S.; Irie, H.; et al. Evaluation of OMI operational standard $\mathrm{NO}_{2}$ column retrievals using in situ and surface-based $\mathrm{NO}_{2}$ observations. Atmos. Chem. Phys. 2014, 14, 11587-11609. [CrossRef]

46. Almaraz, M.; Bai, E.; Wang, C.; Trousdell, J.; Conley, S.; Faloona, I.; Houlton, B.Z. Agriculture is a major source of NOx pollution in California. Sci. Adv. 2018, 4, eaao3477. [CrossRef] [PubMed]

47. Krotkov, N.A.; McLinden, C.A.; Li, C.; Lamsal, L.N.; Celarier, E.A.; Marchenko, S.V.; Swartz, W.H.; Bucsela, E.J.; Joiner, J.; Duncan, B.N.; et al. Aura OMI observations of regional $\mathrm{SO}_{2}$ and $\mathrm{NO}_{2}$ pollution changes from 2005 to 2015. Atmos. Chem. Phys. 2016, 16, 4605-4629. [CrossRef]

48. Malm, W.C.; Sisler, J.F.; Huffman, D.; Eldred, R.A.; Cahill, T.A. Spatial and seasonal trends in particle concentration and optical extinction in the United States. J. Geophys. Res. 1994, 99, 1347-1370. [CrossRef]

49. Blakeslee, R.J. Lightning Imaging Sensor (LIS) on TRMM Science Data [LISOTD_LRMTS_V2.3]; NASA Global Hydrology Center DAAC: Huntsville, AL, USA, 1998.

50. Salomonson, V.V.; Barnes, W.L.; Maymon, P.W.; Montgomery, H.E.; Ostrow, H. MODIS, advanced facility instrument for studies of the Earth as a system. IEEE Trans. Geosci. Remote Sens. 1989, 27, 145-153. [CrossRef]

51. Friedl, M.A.; Sulla-Menashe, D.; Tan, B.; Schneider, A.; Ramankutty, N.; Sibley, A.; Huang, X. MODIS Collection 5 global land cover: Algorithm refinements and characterization of new datasets. Remote Sens. Environ. 2010, 114, 168-182. [CrossRef]

52. Kokkola, H.; Korhonen, H.; Lehtinen, K.E.J.; Makkonen, R.; Asmi, A.; Järvenoja, S.; Anttila, T.; Partanen, A.-I.; Kulmala, M.; Järvinen, H.; et al. SALSA-A Sectional Aerosol module for Large Scale Applications. Atmos. Chem. Phys. 2008, 8, 2469-2483. [CrossRef]

53. Riahi, K.; Gruebler, A.; Nakicenovic, N. Scenarios of long-term socio-economic and environmental development under climate stabilization. Technol. Forecast. Soc. Chang. 2007, 74, 887-935. [CrossRef]

54. Riahi, K.; Rao, S.; Krey, V.; Cho, C.; Chirkov, V.; Fischer, G.; Kindermann, G.; Nakicenovic, N.; Rafaj, P. RCP 8.5-A scenario of comparatively high greenhouse gas emissions. Clim. Chang. 2011, 109, 33. [CrossRef]

55. Randerson, J.T.; van der Werf, G.R.; Giglio, L.; Collatz, G.J.; Kasibhatla, P.S. Global Fire Emissions Database; Version 2 (GFEDv2.1); Oak Ridge National Laboratory Distributed Active Archive Center: Oak Ridge, TN, USA, 2007.

56. Lin, H.; Leaitch, W.R. Development of an in-cloud aerosol activation parameterization for climate modelling. In Proceedings of the WMO Workshop on Measurement of Cloud Properties for Forecasts of Weather, Air Quality and Climate, Geneva, Switzerland; 1997; pp. 328-335. 
57. Guenther, A.; Karl, T.; Harley, P.; Wiedinmyer, C.; Palmer, P.I.; Geron, C. Estimates of global terrestrial isoprene emissions using MEGAN (Model of Emissions of Gases and Aerosols from Nature). Atmos. Chem. Phys. 2006, 6, 3181-3210. [CrossRef]

58. Horowitz, L.W.; Walters, S.; Mauzerall, D.L.; Emmons, L.K.; Rasch, P.J.; Granier, C.; Tie, X.; Lamarque, J.-F.; Schultz, M.G.; Tyndall, G.S.; et al. A global simulation of tropospheric ozone and related tracers: Description and evaluation of MOZART, version 2. J. Geophys. Res. 2003, 108, 4784. [CrossRef]

59. Bian, F.; Bowman, F.M. Theoretical Method for Lumping Multicomponent Secondary Organic Aerosol Mixtures. Environ. Sci. Technol. 2002, 36, 2491-2497. [CrossRef] [PubMed]

60. Robinson, A.L.; Donahue, N.M.; Shrivastava, M.K.; Weitkamp, E.A.; Sage, A.M.; Grieshop, A.P.; Lane, T.E.; Pierce, J.R.; Pandis, S.N. Rethinking Organic Aerosols: Semivolatile Emissions and Photochemical Aging. Science 2007, 315, 1259-1262. [CrossRef] [PubMed]

61. Jacobson, M.Z. Studying ocean acidification with conservative, stable numerical schemes for nonequilibrium air-ocean exchange and ocean equilibrium chemistry. J. Geophys. Res. 2005, 110, D07302. [CrossRef]

62. Kokkola, H.; Yli-Pirilä, P.; Vesterinen, M.; Korhonen, H.; Keskinen, H.; Romakkaniemi, S.; Hao, L.; Kortelainen, A.; Joutsensaari, J.; Worsnop, D.R.; et al. The role of low volatile organics on secondary organic aerosol formation. Atmos. Chem. Phys. 2014, 14, 1689-1700. [CrossRef]

63. Kampf, C.J.; Waxman, E.M.; Slowik, J.G.; Dommen, J.; Pfaffenberger, L.; Praplan, A.P.; Prevot, A.S.H.; Baltensperger, U.; Hoffmann, T.; Volkamer, R. Effective Henry's Law Partitioning and the Salting Constant of Glyoxal in Aerosols Containing Sulfate. Environ. Sci. Technol. 2013, 47, 4236-4244. [CrossRef] [PubMed]

64. Nguyen, T.B.; Coggon, M.M.; Bates, K.H.; Zhang, X.; Schwantes, R.H.; Schilling, K.A.; Loza, C.L.; Flagan, R.C.; Wennberg, P.O.; Seinfeld, J.H. Organic aerosol formation from the reactive uptake of isoprene epoxydiols (IEPOX) onto non-acidified inorganic seeds. Atmos. Chem. Phys. 2014, 14, 3497-3510. [CrossRef]

65. Berrisford, P.; Dee, D.P.; Poli, P.; Brugge, R.; Fielding, K.; Fuentes, M.; Kållberg, P.W.; Kobayashi, S.; Uppala, S.; Simmons, A. The ERA-Interim Archive Version 2.0; ERA Report Series; European Centre for Medium Range Weather Forecasts: Reading, UK, 2011.

66. Boggs, P.T.; Rogers, J.E. Orthogonal Distance Regression. In Statistical Analysis of Measurement Error Models and Applications, Proceedings of the AMS-IMS-SIAM Joint Summer Research Conference, Arcata, CA, USA, 10-16 June 1989; American Mathematical Soc.: Providence, RI, USA, 1990; p. 186.

67. Pitkänen, M.R.A.; Mikkonen, S.; Lehtinen, K.E.J.; Lipponen, A.; Arola, A. Artificial bias typically neglected in comparisons of uncertain atmospheric data. Geophys. Res. Lett. 2016, 43, 10003-10011. [CrossRef]

68. Boggs, P.T.; Byrd, R.H.; Rogers, J.E.; Schnabel, R.B. User's Reference Guide for ODRPACK Version 2.01 Software for Weighted Orthogonal Distance Regression; National Institute of Standards and Technology: Gaithersburg, MD, USA, 1992.

69. Efron, B.; Tibshirani, R. An Introduction to the Bootstrap; Chapman \& Hall/CRC: Boca Raton, FL, USA, 1993; ISBN 0-412-04231-2.

70. Chahine, M.; Pagano, T.S.; Aumann, H.H.; Atlas, R.; Barnet, C.; Blaisdell, J.; Chen, L.; Divakarla, M.; Fetzer, E.J.; Golberg, M.; et al. AIRS improving weather forecasting and providing new data on greenhouse gases. Bull. Am. Meorol. Soc. 2006, 87, 911-926. [CrossRef]

71. Chung, D.; Dorigo, W.; Hahn, S.; Melzer, T.; Paulik, C.; Reimer, C.; Vreugdenhil, M.; Wagner, W.; Kidd, R. Algorithm Theoretical Baseline Document (ATBD) D2.1 Version 04.2 Merging Active and Passive Soil Moisture Retrievals. ESA Climate Change Initiative Phase 2 Soil Moisture Project 2018. Available online: http:/ / www.esa-soilmoisture-cci.org/sites/default/files/documents/M6/CCI2_Soil_Moisture_ DL2.1_ATBD_v4.2_04_merging.pdf (accessed on 8 May 2018).

72. Giglio, L.; Csiszar, I.; Justice, C.O. Global distribution and seasonality of active fires as observed with the Terra and Aqua MODIS sensors. J. Geophys. Res. Biogeosci. 2006, 111, G02016. [CrossRef]

73. Veefkind, J.P.; Boersma, K.F.; Wang, J.; Kurosu, T.P.; Krotkov, N.; Chance, K.; Levelt, P.F. Global satellite analysis of the relation between aerosols and short-lived trace gases. Atmos. Chem. Phys. 2011, 11, 1255-1267. [CrossRef]

74. Blanchard, C.L.; Hidy, G.M.; Tanenbaum, S.; Edgerton, E.S.; Hartsell, B.E. The Southeastern Aerosol Research and Characterization (SEARCH) study: Temporal trends in gas and PM concentrations and composition, 1999-2010. J. Air Waste Manag. Assoc. 2013, 63, 247-259. [CrossRef] [PubMed] 
75. Hand, J.L.; Schichtel, B.A.; Malm, W.C.; Pitchford, M.L. Particulate sulfate ion concentration and $\mathrm{SO}_{2}$ emission trends in the United States from the early 1990s through 2010. Atmos. Chem. Phys. 2012, 12, 10353-10365. [CrossRef]

76. Russell, A.R.; Valin, L.C.; Cohen, R.C. Trends in $\mathrm{OMI} \mathrm{NO}_{2}$ observations over the United States: Effects of emission control technology and the economic recession. Atmos. Chem. Phys. 2012, 12, 12197-12209. [CrossRef]

77. Zhang, H.; Yee, L.D.; Lee, B.H.; Curtis, M.P.; Worton, D.R.; Isaacman-VanWertz, G.; Offenberg, J.H.; Lewandowski, M.; Kleindienst, T.E.; Beaver, M.R.; et al. Monoterpene SOA dominate atmospheric fine aerosol. Proc. Natl. Acad. Sci. USA 2018. [CrossRef]

78. Hu, W.W.; Campuzano-Jost, P.; Palm, B.B.; Day, D.A.; Ortega, A.M.; Hayes, P.L.; Krechmer, J.E.; Chen, Q.; Kuwata, M.; Liu, Y.J.; et al. Characterization of a real-time tracer for isoprene epoxydiols-derived secondary organic aerosol (IEPOX-SOA) from aerosol mass spectrometer measurements. Atmos. Chem. Phys. 2015, 15, 11807-11833. [CrossRef]

79. Surratt, J.D.; Chan, A.W.H.; Eddingsaas, N.C.; Chan, M.; Loza, C.L.; Kwan, A.J.; Hersey, S.P.; Flagan, R.C.; Wennberg, P.O.; Seinfeld, J.H. Reactive intermediates revealed in secondary organic aerosol formation from isoprene. Proc. Natl. Acad. Sci. USA 2010, 107, 6640-6645. [CrossRef] [PubMed]

80. Paulot, F.; Crounse, J.D.; Kjaergaard, H.G.; Kürten, A.; St. Clair, J.M.; Seinfeld, J.H.; Wennberg, P.O. Unexpected Epoxide Formation in the Gas-Phase Photooxidation of Isoprene. Science 2009, 325, 730-733. [CrossRef] [PubMed]

81. Zhang, X.; Hecobian, A.; Zheng, M.; Frank, N.H.; Weber, R.J. Biomass burning impact on PM 2.5 over the southeastern US during 2007: Integrating chemically speciated FRM filter measurements, MODIS fire counts and PMF analysis. Atmos. Chem. Phys. 2010, 10, 6839-6853. [CrossRef]

82. Prospero, J.M. Long-term measurements of the transport of African mineral dust to the southeastern United States: Implications for regional air quality. J. Geophys. Res. 1999, 104, 15917-15927. [CrossRef]

83. Millet, D.; Jacob, D.; Boersma, F.; Fu, T.-M.; Kurosu, T.; Chance, K.; Heald, C.; Guenther, A. Spatial distribution of isoprene emissions from North America derived from formaldehyde column measurements by the OMI satellite sensor. J. Geophys. Res. 2008, 113, D02307. [CrossRef]

84. Haywood, J.M.; Shine, K.P. The effect of anthropogenic sulfate and soot aerosol on the clear sky planetary radiation budget. Geophys. Res. Lett. 1995, 22, 603-606. [CrossRef]

85. Emde, C.; Buras-Schnell, R.; Kylling, A.; Mayer, B.; Gasteiger, J.; Hamann, U.; Kylling, J.; Richter, B.; Pause, C.; Dowling, T.; et al. The libRadtran software package for radiative transfer calculations (version 2.0.1). Geosci. Model Dev. 2016, 9, 1647-1672. [CrossRef]

86. Lihavainen, H.; Asmi, E.; Aaltonen, V.; Makkonen, U.; Kerminen, V.-M. Direct radiative feedback due to biogenic secondary organic aerosol estimated from boreal forest site observations. Environ. Res. Lett. 2015, 10, 104005. [CrossRef]

87. Carlton, A.G.; Turpin, B.J. Particle partitioning potential of organic compounds is highest in the Eastern US and driven by anthropogenic water. Atmos. Chem. Phys. 2013, 13, 10203-10214. [CrossRef] 